\title{
Natural Pest Regulation and Its Compatibility with Other Crop Protection Practices in Smallholder Bean Farming Systems
}

\author{
Baltazar J. Ndakidemi ${ }^{1, *(D)}$, Ernest R. Mbega ${ }^{1}$, Patrick A. Ndakidemi ${ }^{1}$, Philip C. Stevenson ${ }^{2,3}$ (D), \\ Steven R. Belmain ${ }^{2}$, Sarah E. J. Arnold ${ }^{1,2}$ and Victoria C. Woolley ${ }^{2} \mathbb{D}$
}

1 Department of Sustainable Agriculture, School of Life Sciences and Bioengineering, The Nelson Mandela African Institution of Science and Technology, Arusha P.O. Box 447, Tanzania; ernest.mbega@nm-aist.ac.tz (E.R.M.); patrick.ndakidemi@nm-aist.ac.tz (P.A.N.); s.e.j.arnold@greenwich.ac.uk (S.E.J.A.)

2 Natural Resources Institute, University of Greenwich, Chatham Maritime, Kent ME4 4TB, UK; P.C.Stevenson@greenwich.ac.uk (P.C.S.); S.R.Belmain@greenwich.ac.uk (S.R.B.); V.Woolley@greenwich.ac.uk (V.C.W.)

3 Royal Botanic Gardens, Kew, Richmond, Surrey TW9 3DS, UK

* Correspondence: noebien@gmail.com

Citation: Ndakidemi, B.J.; Mbega, E.R.; Ndakidemi, P.A.; Stevenson, P.C.; Belmain, S.R.; Arnold, S.E.J.; Woolley, V.C. Natural Pest Regulation and Its Compatibility with Other Crop Protection Practices in Smallholder Bean Farming Systems. Biology 2021, 10, 805. https:// doi.org/10.3390/biology10080805

Academic Editors: Cesar

Rodriguez-Saona, Paul Abram and Pablo Urbaneja-Bernat

Received: 30 June 2021

Accepted: 9 August 2021

Published: 20 August 2021

Publisher's Note: MDPI stays neutral with regard to jurisdictional claims in published maps and institutional affiliations.

Copyright: (c) 2021 by the authors. Licensee MDPI, Basel, Switzerland. This article is an open access article distributed under the terms and conditions of the Creative Commons Attribution (CC BY) license (https:// creativecommons.org/licenses/by/ $4.0 /)$.
Simple Summary: Bean production by smallholder farmers in sub-Saharan Africa is frequently constrained by insect pests, two of the most serious being Maruca vitrata and Aphis fabae. For many bean farmers, the options available to control these pests are limited. A few can access synthetic insecticides, but these have negative consequences for their health and the environment. Natural pest regulation (NPR) offers environmentally benign approaches for smallholders to manage bean pests. For example, here, we focus on biological control whereby beneficial organisms predate or parasitize the pests. Field studies show this is a feasible strategy for controlling M. vitrata and A. fabae. In particular, we highlight how compatible biological control is with other NPR options, such as the use of biopesticides (including plant extracts), resistant varieties, and cultural control. We recommend that smallholder farmers consider biological control alongside other NPR strategies for reducing the populations of $A$. fabae and M. vitrata in the common bean, increasing the yields and reducing the negative impacts of the synthetic pesticides.

Abstract: Common bean (Phaseolus vulgaris) production and storage are limited by numerous constraints. Insect pests are often the most destructive. However, resource-constrained smallholders in sub-Saharan Africa (SSA) often do little to manage pests. Where farmers do use a control strategy, it typically relies on chemical pesticides, which have adverse effects on the wildlife, crop pollinators, natural enemies, mammals, and the development of resistance by pests. Nature-based solutions -in particular, using biological control agents with sustainable approaches that include biopesticides, resistant varieties, and cultural tools-are alternatives to chemical control. However, significant barriers to their adoption in SSA include a lack of field data and knowledge on the natural enemies of pests, safety, efficacy, the spectrum of activities, the availability and costs of biopesticides, the lack of sources of resistance for different cultivars, and spatial and temporal inconsistencies for cultural methods. Here, we critically review the control options for bean pests, particularly the black bean aphid (Aphis fabae) and pod borers (Maruca vitrata). We identified natural pest regulation as the option with the greatest potential for this farming system. We recommend that farmers adapt to using biological control due to its compatibility with other sustainable approaches, such as cultural tools, resistant varieties, and biopesticides for effective management, especially in SSA.

Keywords: biological control; chemical control; biopesticides; habitat manipulation; predators; parasitoids; Aphis fabae; Maruca vitrata 


\section{Introduction}

The challenge for agriculture today and in the next thirty years is implementing sustainable and ideally carbon zero farming that is economically viable and resilient to future shocks, including the changing climate. This is particularly important in Africa, where $19.1 \%$ of the population was undernourished in 2019 [1], and farmers are increasingly negatively affected by climate change. Agriculture underpins most livelihoods in subSaharan Africa (SSA), because it provides food security, employment, and also contributes to an average of $15 \%$ of the total gross domestic product (GDP) [2,3]. Small-scale farming is common in SSA, but smallholder farms have been neglected by existing studies [4]. It is thought that it will be particularly challenging for smallholders to adopt sustainable intensification, as they are vulnerable to production risks such as climate change [5].

Legumes, including common beans (Phaseolus vulgaris), are frequently grown by smallholder farmers in SSA. Beans are a critically important component of healthy diets in SSA, because they are good sources of protein; vitamins; energy; and micronutrients, e.g., iron, zinc, thiamin, and folic acid [6,7], and have the added benefit of fixing nitrogen through rhizobial interactions [7]. Therefore, the common bean and other legumes are ideal crops for increasing food security, improving soil quality, and enhancing livelihoods through increased income in SSA [8]. However, the yield of these grain legumes is constrained by insect pests [9]. For example, the common bean has an average yield gap of $2.6 \mathrm{Mg} \mathrm{ha}^{-1}$ across Ethiopia, Kenya, and Tanzania [10]. Reducing this gap could significantly increase the food security in these areas. The insect legume pests that cause yield reductions in common beans across SSA include scarab beetles (Schizonycha spp.), foliage beetles (Ootheca bennigseni and Ootheca mutabilis), black bean aphids (Aphis fabae and Aphis craccivora), bean stem maggots (Ophiomyia phaseoli and Ophiomyia spencerella), bean pod borers (Maruca vitrata and Helicoverpa armigera), tobacco whiteflies (Bemisia tabaci) biotype B, the Southern green stink bug (Nezara viridula), and the storage pest bean bruchid (Callosobruchus maculatus) [11-14]. The use of pest control strategies for most farmers in SSA is limited by the factors related to monetary cost, a lack of knowledge, and limited research on different products [15]. Synthetic pesticides are expensive for smallholder farmers, but they also have negative impacts on human health, the environment [16], and nontarget organisms such as natural enemies and pollinators [17]. Thus, there is a need for effective alternatives to suppress crop pests [18]. Natural pest regulation (NPR) offers an alternative for pest management in SSA and is an essential component of an integrated pest management system. NPR is an approach to pest management that relies on beneficial insects and biological approaches. It includes practices that are sustainable and are best-suited to smallholder farmers such as habitat manipulation to enhance the contribution and use of biological control agents $[19,20]$, biopesticides including botanical insecticides [21], breeding for hostplant resistances [22], pheromones for mating disruptions [23], and cultural control [24]. Although there has been much research on developing these sustainable pest management options, there are few field-ready options targeted at or developed for smallholder farmers, especially in SSA and particularly for M. vitrata and A. fabae, which cause major yield losses (Table 1). Here, we critically review the existing methods to control $A$. fabae and M. vitrata sustainably using biological control techniques and their compatibility with other sustainable control strategies. Recommendations regarding the future directions of research and effective management options for these pests are presented, and the current challenges in sustainable pest management faced by smallholder farmers, especially in SSA, are discussed in the context of available options.

Table 1. The empirically assessed bean yield losses attributed to black bean aphid (Aphis fabae) and bean pod borer (Maruca vitrata) in East African countries per year.

\begin{tabular}{cccc}
\hline Bean Pest & Country & Yield Loss $\%$ & Reference \\
\hline A. fabae & Burundi & 50 & {$[25]$} \\
\hline
\end{tabular}


Table 1. Cont.

\begin{tabular}{cccc}
\hline Bean Pest & Country & Yield Loss $\%$ & Reference \\
\hline A. fabae & Kenya & $37-90$ & {$[26]$} \\
\hline A. fabae & Tanzania & 37 & {$[27]$} \\
\hline A. fabae & Uganda & 90 & {$[28]$} \\
\hline M. vitrata & Tanzania & $33-53$ & {$[29]$} \\
\hline M. vitrata & Kenya & $15-25$ & {$[30]$} \\
\hline
\end{tabular}

\section{Selected Common Bean Pests: Bean Pod Borer (Maruca vitrata) and Black Bean Aphid (Aphis fabae)}

Maruca vitrata and A. fabae (Figures 1 and 2) are the pests of the greatest economic importance in beans, as they account for the major yield losses in SSA (Table 1). Maruca vitrata is a lepidopteran pest, the larvae of which reduce the yield by feeding on bean flowers, buds, and pods [31]. This pest is widely distributed in the tropics and subtropics and is highly destructive in many parts of Africa and Asia [32-34]. It has previously been recorded as causing between 15\% and 53\% yield losses in East African countries (Table 1). Another key pest of legumes in SSA is A. fabae, which causes damage by direct feeding; it is also responsible for the spread of several plant diseases, including cucumber mosaic virus (CMV), bean common mosaic necrosis virus (BCMNV) and bean common mosaic virus (BCMV) [35]. Aphis fabae can cause between 37\% and 90\% yield losses in East African countries (Table 1). Several host plants are associated with $A$. fabae and M. vitrata (see Table 2).

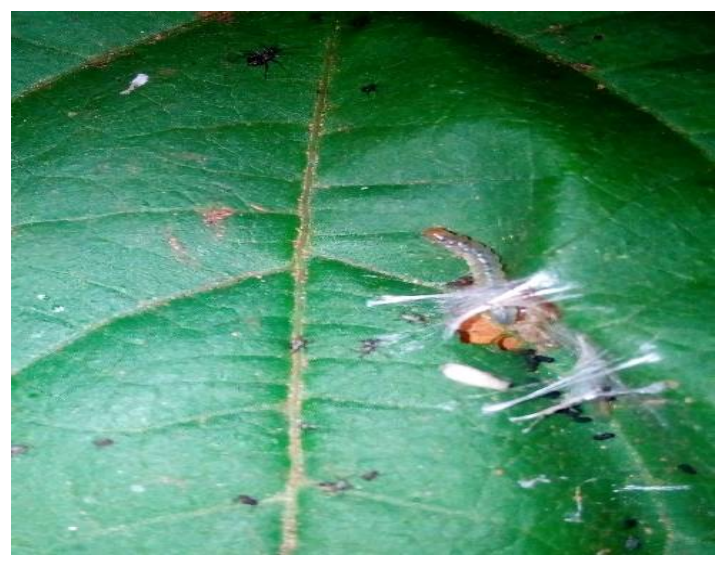

(a)

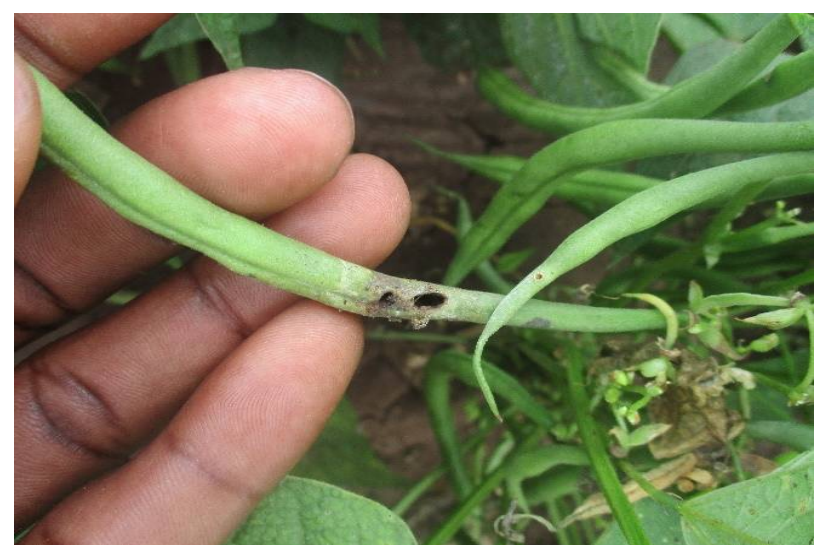

(b)

Figure 1. (a) M. vitrata larva and (b) pod damage by M. vitrata larva. Maruca vitrata infestation in beans (Photograph by Baltazar Ndakidemi, NM-AIST-Arusha, Tanzania).

Table 2. Host plant species for Maruca vitrata and Aphis fabae.

\begin{tabular}{cccc}
\hline Bean Pest & Plant Species & Family & References \\
\hline M. vitrata & Vigna unguiculata & Fabaceae & {$[36,37]$} \\
\hline M. vitrata, A fabae & Phaseolus vulgaris & Fabaceae & {$[36]$} \\
\hline M. vitrata & Cajanus cajan & Fabaceae & {$[31]$} \\
\hline M. vitrata, A. fabae & Phaseolus lunatus & Fabaceae & {$[31,38,39]$} \\
\hline M. vitrata & Sesbania sp. & Fabaceae & {$[40]$} \\
\hline M. vitrata & Crotalaria sp. & Fabaceae & {$[41]$} \\
\hline
\end{tabular}


Table 2. Cont.

\begin{tabular}{cccc}
\hline Bean Pest & Plant Species & Family & References \\
\hline M. vitrata & Sesbania pachycarpa & Fabaceae & {$[42]$} \\
\hline M. vitrata, A. fabae & Vicia faba & Fabaceae & {$[31,43]$} \\
\hline A. fabae & Beta vulgaris & Amaranthaceae & {$[44,45]$} \\
\hline A. fabae & Solanum tuberosum & Solanaceae & {$[46]$} \\
\hline A. fabae & Allium cepa & Amaryllidaceae & {$[39]$} \\
\hline A. fabae & Lycopersicon esculentum & Solanaceae & {$[46]$} \\
\hline A. fabae & Dahlia pinnata, Lactuca sativa & Asteraceae & {$[39,46]$} \\
\hline
\end{tabular}
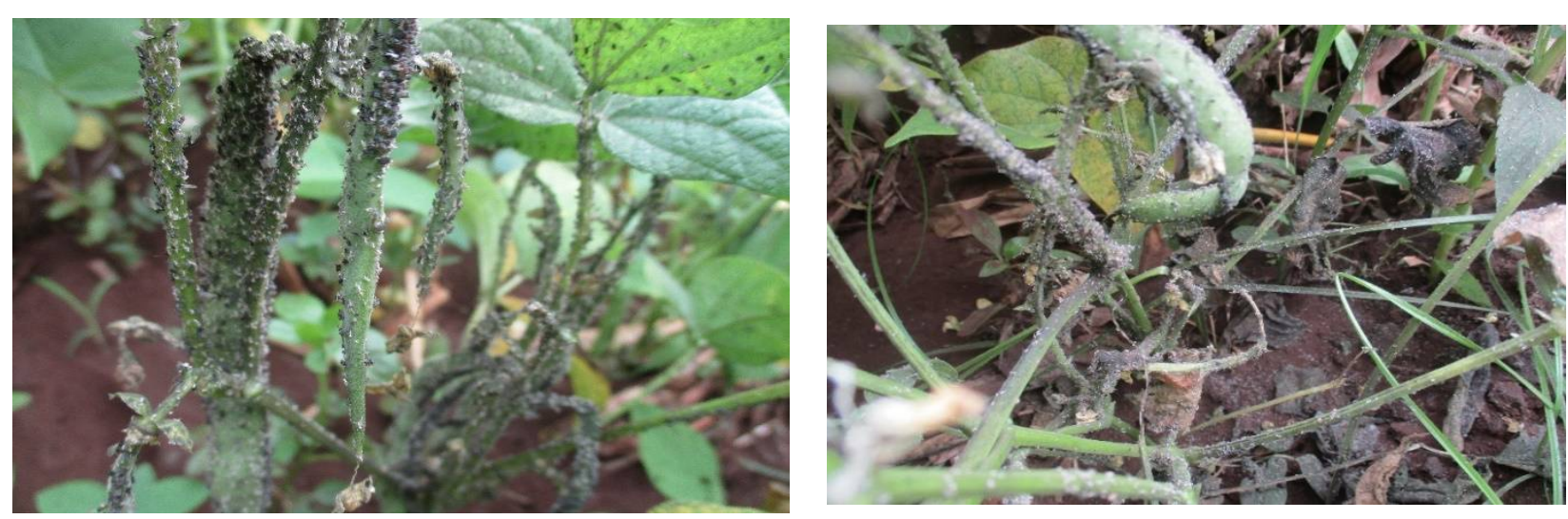

Figure 2. Aphis fabae infestation in beans (Photograph by Baltazar Ndakidemi, NM-AIST-Arusha, Tanzania).

\section{The Use of Biological Control as a Central Focus for Aphis fabae and Maruca vitrata Control}

Due to the health and environmental hazards of synthetic pesticides, biological control has been proposed as an alternative in legumes [47]. Natural enemies can be an important components of integrated pest management (IPM) in agricultural fields and are environmentally benign compared with synthetic chemical pesticides and, in many cases, are economically viable [48]. IPM is a decision-based sustainable approach that utilizes all suitable pest management techniques (biological, cultural, physical/mechanical, and chemical methods) to reduce and/or manage pest populations, diseases, and weeds [49]. Thus, biological control is the process of NPR whereby natural enemies (predators and parasitoids) control populations of other plants and animals (e.g., insect pests) [50]. These beneficial organisms (also called biocontrol agents) control pests by different mechanisms, such as parasitism, predation, and competition [51]. There are three types of biological controls: conservation, classical, and augmentative [52]. Conservation biological control involves human interactions to enhance these natural enemies' populations. For classical biological control, non-native natural enemies are released into areas where pests are invasive for permanent suppression, while augmentative biological control involves the mass rearing and release of native natural enemies for controlling pests [53-55]. A lack of knowledge about these control methods among farmers in SSA could be responsible for their lack of adoption [9].

Conservation biological control may be the most accessible form of biological control for smallholder farmers in SSA, because they can implement affordable field-scale interventions, such as increasing the local plant diversity and abundance, to enhance the natural enemy populations [56-58]. Predators/parasitoids can be attracted to crops through the provision of floral resources (nectar and pollen) in the vicinity and suitable habitats [59-63]. However, farmers' knowledge of natural enemies and how to conserve them is a constraint 
to using this form of biological control [64]. More studies are required to identify the key roles played by natural enemies in managing important legume pests and their benefits over synthetics [9]. Natural enemies interact with field margins for resources and shelter, and this can enhance the biological control of pests in field crops [57,58]. This supports the importance of bean field margins in promoting natural enemies within bean crops. However, few field studies have investigated the impacts of different plant manipulations on the populations of natural enemies for suppressing pests such as A. fabae [65] and M. vitrata in legumes.

Several natural enemies have been identified for controlling $M$. vitrata at all developmental stages (Table 3). Both $M$. vitrata adult and larval predators have been investigated for their potential as effective biological control agents. The predators identified for $M$. vitrata include the Araneidae (Nephila maculata), Oxypidae (Oxyopes javanus), Anthocoridae (Orius tantillus), Forficulidae (Diaperasticus erythrocephala), and Formicidae (Camponotus rufoglaucus) [66]. Parasitoids of $M$. vitrata have been identified across a range of crops, including common beans and Sesbania cannabina. The hymenopteran larval parasitoids identified in SSA include Braunsia kriegeri, Apanteles taragamae, Pristomerus sp., Bassus bruesi, Testudobracon sp., Cadurcia sp., Phanerotoma syleptae, Dolichogenidea spp. and Phanerotoma leucobasis [67-71]. The egg parasitoids include P. syleptae and Trichogramma spp. [67,72-74]. Tachinid flies have also been identified as larval parasitoids $[67,68]$.

Table 3. Parasitoids of Maruca vitrata that have been reported in SSA.

\begin{tabular}{clcc}
\hline Parasitoid Species & Family & Host Stage Parasitized & References \\
\hline Apanteles taragamae & Braconidae & Larva & {$[75]$} \\
\hline Bassus bruesi, Bracon sp. & Braconidae & Larva & {$[68]$} \\
\hline Braunsia kriegeri & Braconidae & Larva & {$[67,68]$} \\
\hline Cadurcia sp. & Tachinidae & Larva & {$[68]$} \\
\hline Dolichogenidea sp. & Braconidae & Larva & {$[68,70]$} \\
\hline Phanerotoma leucobasis & Braconidae & Larva & {$[58]$} \\
\hline
\end{tabular}

The biological control of aphids is particularly difficult because of their high reproductive rates [76]. However, several aphid predators have been reported [77-80]. The predators of A. fabae (Table 4) include Coccinellidae; Cantharidae; Diptera (Dolichopodidae, Tachinidae, Syrphidae larvae, and Cecidomyiidae larvae); Staphylinidae; Hymenoptera (Vespidae and Polistinae); Hemiptera (Anthocoridae); and Neuroptera larva (Chrysopidae) [81-85]. Coccinellids are particularly effective predators of $A$. fabae [86,87]. Hippodamia variegata has been closely associated with $A$. fabae control in Kenya, while other predatory coccinellids associated with the control of $A$. fabae include Cheilomenes spp., Henosepichna spp. and Exochomus spp. [86]. Studies on A. fabae parasitoids have identified the braconid Aphidius colemani as the main primary parasitoid of $A$. fabae in Tanzania, although it is not yet known whether it is also present in other SSA countries $[83,88]$.

Table 4. Natural enemies for black bean aphids (Aphis fabae), also recorded in SSA.

\begin{tabular}{ccc}
\hline Natural Enemy & Family & References \\
\hline Aphidius colemani & Aphididae & {$[83,88]$} \\
\hline Cheilomenes sp. & Coccinellidae & {$[86]$} \\
\hline Exochomus spp. & Coccinellidae & {$[86]$} \\
\hline Henosepichna spp. & Coccinellidae & {$[86]$} \\
\hline Hippodamia variegata & Coccinellidae & {$[86,89]$} \\
\hline
\end{tabular}


When considering the use of natural enemies for pest control, it is crucial to understand how the biotic and abiotic factors influence them. For example, the rate of parasitism by A. taragamae decreases as the temperature increases, although this varies depending on the age of the larva. The first and second instars of $M$. vitrata larva are parasitized to a great extent, while the older larvae are not, which is likely due to the defensive behavior in older larvae [75]. Conversely, the parasitism by A. colemani decreases linearly with the temperature [90]. The competition for prey also can reduce parasitism [91]. These variables inform how best to deploy NPR in the field.

\section{Ecological Manipulations for Supporting Natural Enemies}

Generally, conservation biological control utilizes plant and landscape biodiversity to promote beneficial insect populations by carefully modifying and managing the environment to increase non-prey resources [92-96]. Farmscaping is one term used to describe an ecological approach that enhances the biodiversity to augment the presence of beneficial organisms. Terms such as conservation biological control and ecological engineering are also used to describe similar interventions. Conservation biological control seeks to utilize the existing environmental components to support natural enemies [20]. Thus, ecological engineering and farmscaping are the strategies that are used in conservation biological control. Ecological engineering involves practices and interventions that aim to maximize the benefit of habitat management in suppressing agricultural pests [20]. Farmscaping provides suitable plants to support and attract populations of beneficial insects [97]. It forms the basis for ecological intensification or sustainable intensification, i.e., maximizing the ability of the system to produce food sustainably [98]. Farmscaping provides places for insects to overwinter, physical refugia, and forage; it may also act as a habitat for alternative prey and hosts $[61,62,94,99]$. Habitat management involving the manipulation of farmland vegetation can exert direct suppressive effects on pests and promote natural enemies [94]. Examples include the use of trap crops, hedgerows, field margins, and cover crops. Habitat disturbance, loss, and fragmentation in agroecosystems may lead to unsuitable environments for natural enemies [97]. Increasing landscape diversity through manipulating the plants that provide alternative resources to natural enemies such as pollen and nectar is therefore important for augmenting NPR and pollination [92,100]. A recent meta-analysis demonstrated a positive effect of flower strips on pest control compared to the fields without flower strips [101]. However, farmscaping might support pest populations, as some herbivores will depend on sugar and floral resources [102-104]. For instance, several studies reported that there was no effect of habitat manipulation on either pest or natural enemy abundances $[105,106]$. Therefore, it is vital to understand how natural enemies and pests interact with plants before assuming that increased diversity might improve the conservation biological control.

Several flowering plants found in SSA have been used in farmscaping. Fagopyrum esculentum, Lobularia maritima, Mentha piperita, Tridax procumbens, Tagetes erecta, Tagetes minuta, and Sesamum indicum, for example, have been found to increase the parasitism rates and longevity of lepidopteran and aphid's natural enemies, such as Apanteles ruficrus, Cotesia chilonis, Cotesia rubecula, Trichogramma chilonis, Microplitis mediator, Diadegma semiclausum, and A. colemani; thus, they could have potential for M. vitrata and A. fabae management [106-109]. However, as some of these species are invasive to SSA, they should be used cautiously. Crops such as sorghum used as a border in pigeon pea fields increase the abundance of the predators Coccinella septumpunctata, Cheilomenes sexmaculata, and spiders, with a decrease in $M$. vitrata populations, which eventually leads to increased pigeon pea yields [110].

Farmscaping plants can also influence the behavior of phytophagous and predatory insects through the volatiles they produce [111,112]. Volatiles are involved in signaling and therefore play a part in the defense against various pathogens and herbivores and attract beneficial insects [113]. Intercropping some plants that release volatiles when damaged by herbivores will attract natural enemies of pests to an area. Some semiochemicals produced 
by plants when attacked by herbivores or synthetic equivalents will repel pests and attract natural enemies and are known as Herbivore-Induced Plant Volatiles (HIPVs) [114,115]. These can be used to improve the conservation biological control. For instance, volatiles released by damaged $M$. vitrata host plants (cowpea and pea bush) attracted the braconid Therophilus javanus and the parasitic fly Nemorilla maculosa $[73,116]$. This was also the case for volatile compounds produced by Vicia faba damaged by A. fabae, which attracted a parasitoid (Lysiphlebus fabarum) and a predator (Orius albidipennis) [117]. The use of synthetic HIPVs in attracting $M$. vitrata parasitoids was successful for A. taragamae and P. syleptae [118]. The mechanism of how HIPV functions could also be necessary for providing the control of $A$. fabae, and this requires further studies. Non-crop habitats such as field margins are essential in providing floral resources to natural enemies. Therefore, selecting suitable plants to attract/conserve natural enemies is essential in establishing the effective biological control of pests. Future studies should focus on different host plants and how they influence the abundance of insect pests and natural enemies and manipulate them for effective biological control.

\section{Synthetic Chemicals and Their Impact on Natural Enemies of Maruca vitrata and Aphis fabae}

Synthetic pesticides can provide the rapid knockdown of pests and reduce crop damage and yield losses when used correctly, but they also have negative impacts on human health and the environment, which can be a particular problem in SSA, where farmers often use older, more toxic, mislabeled pesticides that are more likely to be incorrectly handled and sprayed $[119,120]$. Issues such as mixing different types of chemicals and the increasing frequency and application rates further magnify the problems and create a need for environmentally friendly pest management [47]. In the context of biological pest control, pesticides can also kill nontarget organisms, such as the natural enemies of pests and pollinators, and so are detrimental to sustainable pest control [65].

The chemical control of $M$. vitrata is difficult, because their feeding sites in floral parts and pods protect the larvae from sprays [121,122], so NPR using biological pest control is more appropriate for this pest. Pesticide resistance to cypermethrin and dimethoate has also been reported in $M$. vitrata, making their control more challenging [123]. Farmers sometimes use doses of synthetic pesticides above the recommended rates to achieve control of $M$. vitrata, which increases nontarget impacts and risks and exacerbates the build-up of pesticide resistance [123]. Where farmers are provided knowledge and support, sustainable pest management strategies and a decreased reliance on synthetic pesticides are feasible [64].

Recent evidence has shown that a number of natural enemies of $A$. fabae, including Coccinellidae, Araneidae, Syrphidae, and Chrysopidae, were significantly lower in fields treated with the synthetic chemical pesticide Karate 5 EC (lambda-cyhalothrin) in common bean, cowpea, and pigeon pea field trials compared to those treated with botanicals $[65,124,125]$. Other studies have reported lethal and nonlethal effects of synthetic pesticides on arthropod natural enemies, such as feeding deterrents and mortality [126-131].

NPR that optimizes the services of natural enemies of $A$. fabae and $M$. vitrata is likely to be the basis of sustainable pest management. Since most synthetic pesticides are not compatible with beneficial insects, they will likely be used as the last resort in future sustainable farming systems. Thus, in searching for sustainable pest control, biological control stands as a cornerstone of other sustainable strategies and is favored for its feasibility [36], especially for smallholder farmers. However, smallholder farmers require knowledge support of biological control, as knowledge gaps hinder the adoption of conservation biological control [47,64]. Hence, it is important to make a proper advocacy of biological control for sustaining ecosystem services offered by the natural enemies of pests. 


\section{Other Sustainable Alternatives Compatible with Natural Enemies for Managing Maruca vitrata and Aphis fabae}

\subsection{Biopesticides}

Biopesticides are natural products or microorganisms that act as alternatives to conventional pesticides and are nonpersistent in the environment, reducing the harmful effects of conventional pest control that rely on synthetic products [21,132-135]. Biopesticides are categorized into three groups: microbial pesticides, plant-incorporated protectants (PIPs), and biochemical pesticides or plant-based pesticides (PBPs) [136]. Some biopesticides can be used alone, while others can be coapplied with other control methods-in particular, the natural enemies of pests. Biopesticides can interact with other control options, especially natural enemies, and exhibit additive or antagonistic effects in their control of pests [137].

Microbial biopesticides consist of formulated microorganisms, including bacteria, fungi, protozoa, nematodes, and viruses, that are pathogenic to insects $[132,136]$ and have been investigated for the management of M. vitrata and A. fabae. For example, Bacillus thuringinesis $(\mathrm{Bt})$ and its toxins are one of the most widely used and successful microbial biopesticides [138] and have been successfully used to control $M$. vitrata based on the activity of Bt $\delta$-endotoxins [139], while a commercial Bt product (Bactospeine) causes larval mortality [140]. The efficacy of Bt against $M$. vitrata has also been assessed in the field on yard-long beans, where its application in combination with PBPs such as neem is effective in reducing pod damage by $M$. vitrata [72]. However, the effects of these technologies on the natural enemies of pests are not well-studied and require more attention to determine the compatibility across sustainable approaches to pest management.

Viruses also have efficacy against $M$. vitrata, although most studies have been based in the laboratory [141]. The baculovirus, $M$. vitrata multi-nucleopolyhedrovirus (MaviMNPV), is a promising candidate as a biopesticide against $M$. vitrata and has been researched for use in SSA in particular. This virus causes significant mortality and reduces the egg viability of M. vitrata under laboratory conditions [142]. It has also been demonstrated to be effective against $M$. vitrata larva both in the field and in laboratory bioassays. Furthermore, its efficacy can be increased when applied with neem oil and neem, Azadirachta indica, and Jatropha curcas extracts [143-145], as evidence of its compatibility with other technologies. There have been attempts to develop techniques to mass produce MaviMNPV for smallholder farmers in SSA by the International Institute of Tropical Agriculture (IITA-Benin). Although this has not yet been implemented in smallholder farms on a large scale, it has the potential to control $M$. vitrata in a more cost-efficient and sustainable way [146]. Biopesticides for A. fabae and M. vitrata are shown in Table 5. The compatibility of microbial biopesticides with the natural enemies of pests has been reported. For instance, the baculovirus M. vitrata multi-nucleopolyhedrovirus (MaviMNPV) showed compatibility with the braconid parasitoid A. taramagae, and the parasitoid can transmit the virus between hosts [145].

Similarly, the entomopathogenic fungi (EPF) biopesticide Beauveria bassiana is compatible with the predatory coccinellids $C$. septempunctata and H. variegata $[147,148]$, while Lecanicillium muscarium, in combination with the predatory coccinellid Adalia bipunctata, showed the possibility of reducing A. fabae infestations, although this was not in the field setting, and thus, further field trials are needed [149]. Likewise, a combination of the EPF Metarhizium anisopliae with the PBP pyrethrum does not affect the foraging behavior of A. colemani, a key parasitoid of $A$. fabae, implying a likely compatibility. However, when used alone, the EPF exhibited a deterrent effect in $A$. colemani, so more research is needed [150].

Table 5. Microbial biopesticides used in the control of Aphis fabae and Maruca vitrata.

\begin{tabular}{ccc}
\hline Bean Pest & Biopesticide Used & References \\
\hline M. vitrata & Bacillus thuringiensis & {$[140]$} \\
\hline M. vitrata & Beauveria bassiana & {$[141,145,151]$} \\
\hline
\end{tabular}


Table 5. Cont.

\begin{tabular}{ccc}
\hline Bean Pest & Biopesticide Used & References \\
\hline M. vitrata & Mavi multi-nucleopolyhedrovirus & {$[141,142]$} \\
\hline M. vitrata & Metarhizium anisopliae & {$[151,152]$} \\
\hline A. fabae & Lecanicillium muscarium & {$[153,154]$} \\
\hline A. fabae & Simplicillium lamellicola & {$[153,154]$} \\
\hline A. fabae & Aspergillus flavus & {$[155]$} \\
\hline M. vitrata & Heterorhabditis sp., Oscheius sp. & {$[156]$} \\
\hline
\end{tabular}

Although biopesticides, including EPFs, B. thuringiensis, entomopathogenic nematodes, and baculovirus-based products that target pests other than M. vitrata and A. fabae, are available commercially in SSA countries such as Kenya [146] and Tanzania [135], the knowledge of their production, the high cost of buying them, and their low speed of killing pests have made farmers reluctant to adopt these control options [135]. The efficacy of biopesticides may be altered by factors such as the humidity, rainfall, temperature, ultraviolet light, leaf surface chemistry, formulation, application method, substrate, and fungal isolates, meaning that their inappropriate use can give poor results $[157,158]$. Therefore, all these factors are to be considered in the formulation for increasing the efficacy of biopesticides for the sustainable control of pests.

Many EPFs affect specific orders of arthropods differently and may therefore pose a lower risk to natural enemies than target pests and, so, can be used effectively with natural enemies $[159,160]$. Conversely, some biopesticides, such as the EPF B. bassiana, infect and kill parasitoids such as A. colemani [161], and therefore, toxicity assays are critical in understanding the wider consequences of applying biopesticides for managing pests.

PBPs exploit naturally occurring entomotoxins of plant origin. They contain metabolites that can inhibit and kill directly, affect reproduction, and alter other metabolic processes in pests $[136,162]$. PBPs can be highly toxic but have typically had lower environmental impacts than synthetic pesticides, primarily because they do not persist in the environment and are broken down through the actions of sunlight and microorganisms [65,124]. Thus, the longer-term impacts on natural enemies and biological control are reduced. The potential of PBPs has been explored in some African countries. However, few of these pesticides have been exploited commercially or in smallholder farms, although some, such as pyrethrum and neem, have been developed into highly successful commercial products [163]. PBPs are compatible with natural enemies and can potentially be used in SSA $[124,125]$. Many PBPs have significantly reduced the negative impacts on beneficial invertebrates compared to synthetic chemical pesticides [124,125]. For example, extracts of Bidens pilosa, Lippia javanica, Tephrosia vogelii, Lantana camara, Vernonia amygdalina, and Tithonia diversifolia were highly effective at controlling insect pests on legume crops, but their impact on lady beetles, lacewings, spiders, and syrphid flies was reportedly significantly lower than those resulting from exposure to synthetic pesticides $[21,65,124,125]$. However, several studies outside SSA have also shown that some PBPs exhibit a toxicity to the natural enemies of pests. For instance, pyrethrum, neem, Chilean plant products, and rotenone caused the mortality of the natural enemies Adonia variegata, Venturia canescens, Orius laevigatus, and Encarsia formosa [164-167].

PBPs, including commercially available products such as Neem Baan (Azadirachtin), have been found to cause $M$. vitrata larval mortality, although their efficacy is reduced when applied to the later larval stages [140]. Due to the cost of commercial PBPs, it may be more viable for smallholder farmers in SSA to use extracts (Table 6) that are prepared by themselves and that are readily available and accessible [134,168]. For instance, multiple pesticidal plant extracts from common margin plants and weeds have shown efficacy against $A$. fabae, including A. indica, Allium sativum, Eucalyptus sp., Swietenia sp., Tephrosia vogelii $[169,170]$, Matricaria chamomilla on the broad bean, and tobacco water (Nicotiana 
sp.) on yard-long beans [171]. Additionally, Annona muricata and Piper guineense extracts significantly reduced $M$. vitrata larval infestations and, thus, increased cowpea yields compared with the synthetic pesticide lambda-cyhalothrin in cowpeas [172].

Table 6. Pesticidal plants common to SSA used for different pest controls.

\begin{tabular}{cccc}
\hline Pesticidal Plant & Family & Family & References \\
\hline Ageratum conyzoides & Asteraceae & Tribolium castaneum & {$[173]$} \\
\hline Allium satioum & Amaryllidaceae & Aphis fabae & {$[169]$} \\
\hline Annona muricata & Annonaceae & Maruca vitrata & {$[172]$} \\
\hline Azadirachta indica & Meliaceae & Aphis fabae & {$[169]$} \\
\hline Eucalyptus sp. & Myrtaceae & Aphis fabae & {$[169]$} \\
\hline Euphorbia heterophylla & Euphorbiaceae & Sitophilus zeamais & {$[174]$} \\
\hline Matricaria chamomilla & Asteraceae & Aphis fabae & {$[172]$} \\
\hline Ocimum sp. & Lamiaceae & Didyctium sp. & {$[175]$} \\
\hline Parthenium hysterophorus & Asteraceae & Aphis craccivora & {$[176]$} \\
\hline Piper guineense & Piperaceae & Maruca vitrata & {$[172]$} \\
\hline Swietenia sp. & Meliaceae & Aphis fabae & {$[169]$} \\
\hline Tephrosia purpurea & Fabaceae & Odoiporus longicollis & {$[177]$} \\
\hline Tephrosia vogelii & Fabaceae & Aphis fabae & {$[124,170]$} \\
\hline
\end{tabular}

Many more plant extracts and their compatibility with natural enemies have not yet been investigated. Additionally, the use of plant products to control M. vitrata is practically limited, because little research has been conducted on PBPs targeting M. vitrata, despite using some of these plants in managing $A$. fabae $[65,124,125]$. As the M. vitrata larva feeds inside the pods, flowers, and flower bud and also webs the leaves and flowers, it is protected from spraying with PBPs as much as with synthetics, making foliar sprays difficult to apply effectively [31]. The lack of field trials and field data, particularly for legume crops in Africa, and the toxicity of some PBPs are the drawbacks of effective pest management. Thus, further studies should address these aspects for the effective control of bean pests.

Plant-incorporated protectants (PIPs) are biopesticides such as the gene encoding the Bt toxin that can be introduced into the plant genome that allows the plant to produce this toxin and increases the resistance of the plant to some pests [178]. For instance, the Cry proteins expressed in Bt cowpeas have shown a less negative effect on nontarget organisms [179]. Generally, the PIPs available globally for the specific management of $M$. vitrata and $A$. fabae are limited, and equally, their impacts on their natural enemies have not been studied; thus, more work has to be done to address this gap.

There is considerable effort for biopesticides to be used more widely in SSA for pest control. However, studies have shown that there is generally a lack of awareness of biopesticide products among smallholder farmers. Across Uganda and Kenya, fewer than $20 \%$ of the farmers surveyed had heard of biopesticides [180], and in Kenya, only $10 \%$ of the farmers surveyed had used biopesticides on their crops [181]. The lack of information could be one of the key factors preventing the broader use of biopesticides across SSA. Other potential barriers to the uptake of biopesticides include the production, cost of buying them, concern over their speed of killing pests, and short persistence. Expertise on product development, packaging, and composition; the knowledge gap among smallholder farmers; and research on the importance and benefits of biopesticides such as ecological safety and the possession of nutrient supplements that are advantageous to crops should be addressed [134]. 


\subsection{Use of Resistant Varieties with Natural Enemies}

The use of resistant varieties is an important component of IPM in controlling legume pests [182]. The use of resistant varieties has shown some level of effectiveness in legumes such as cowpeas [183]. Some M. vitrata-resistant varieties have been identified [184-186]. Fewer studies have been conducted on the use of resistant varieties to reduce $M$. vitrata infestations in the common bean, and therefore, this requires more work, especially considering the impacts on nontarget species that might be exposed to these toxins through parasitizing or by predating the pests. For $A$. fabae management, effective, resistant varieties of $P$. vulgaris have been identified both inside [187] and outside [188] SSA. Cultivars of $V$. faba and Beta vulgaris resistant to A. fabae have similarly been identified $[189,190]$. Resistant cultivars have been used in combination with the natural enemies of bean pests for better pest control. For example, the combined effect of using partially resistant cultivars of $V$. faba with the coccinellid predator C. septempunctata was effective in the control of A. fabae [189]. However, studies to test the different resistant bean varieties and their compatibility with the natural enemies of bean pests for maximizing the biological control services in bean fields are needed.

\subsection{Cultural Control}

Control practices such as mixed cropping systems, variations in planting dates, plant density, and spacing can be effective against $A$. fabae and $M$. vitrata; furthermore, they are beneficial for natural enemies $[24,131,191,192]$. The low incidence of $M$. vitrata larva and flower pod damage was observed in intercropping systems compared to monocropping systems in some studies [193,194]. However, several other studies showed no evidence of the use of intercropping systems in reducing the M. vitrata effects $[195,196]$. Thus, it is important to generate information on the limitations and opportunities of employing intercropping approaches in combating $M$. vitrata, especially in common beans, because currently, there are limited studies on this, especially where they enhance the natural enemy benefits.

Cultural practices may not always benefit pest control. For example, manipulations and variations in planting dates, weeding, and spacing did not help in reducing $M$. vitrata populations but, rather, increased the pest populations [191,197]. Contrarily, a previous study showed that early cowpea planting reduces the rates of infestations by $M$. vitrata [198]. For A. fabae, it was observed that intercropping P. vulgaris with Zea mays was successful in reducing aphid populations in P. vulgaris [199]. Currently, limited studies have been conducted to examine the applicability of different cultural practices for A. fabae management in P. vulgaris. Therefore, it is of importance to assess the potential of different cultural practices in combination with natural enemies and the biological control of bean pests to reduce $A$. fabae infestations in common bean fields.

The compatibility of cultural practices with natural enemies of $M$. vitrata and A. fabae has been reported. The assessment of the intercropping of cowpeas with either green gram or sorghum revealed a high abundance of predators (coccinellids, hoverflies, rove beetles, spiders, praying mantis, ground beetles, predatory mites, big-eyed bugs, dragonflies, damsel bugs, minute pirate bugs, and earwigs) [131]. Conversely, intercropping sorghum with a cowpea crop did not produce significant differences in $M$. vitrata populations, although the parasitism rate by P. leucobasis was higher in the intercropping plots [185]. The coccinellid populations ( $H$. variegata and $C$. septempunctata), important natural enemies of $A$. fabae, were enhanced by intercropping faba beans with the aromatic flowering plant dragonhead (Dracocephalum spp.) [200]. However, limited studies have been conducted to evaluate the compatibility of other cultural control practices with the natural enemies of A. fabae and M. vitrata, particularly in beans.

\section{Conclusions and Recommendations}

Synthetic pesticides are still the most frequently used management strategy to control $M$. vitrata and $A$. fabae by smallholder farmers in bean farming systems, yet are largely 
incompatible with a biological control that is dependent on beneficial insects. Here, we reviewed more sustainable approaches to the pest management of these pests in beans and compared their compatibility with other natural pest-regulating options. Ultimately, there is inadequate evidence to indicate how suitable different approaches might be from the existing literature, and this needs to be addressed. However, where there is evidence, this strongly supports the notion that more sustainable pest management interventions are more compatible with biological control than synthetic pesticides (Table 7). The deployment of sustainable approaches for M. vitrata and A. fabae management for biopesticides faces challenges. For example, the use of biopesticides is limited by the lack of field trials, and thus, farmers have a poor perception of their effectiveness, high cost of production, challenges facing their registration, and hence, few biopesticides are available commercially. More field trials, increasing awareness, and the registration of new products at affordable prices are strategies that would enable farmers in SSA to use more biopesticides.

Table 7. The compatibility of the Maruca vitrata (MV) and Aphis fabae (AF) management options with their natural enemies.

\begin{tabular}{|c|c|c|c|c|c|c|c|c|c|c|c|c|c|c|}
\hline \multirow{4}{*}{$\begin{array}{c}\text { Biological } \\
\text { Control } \\
\text { Agent }\end{array}$} & \multicolumn{14}{|c|}{ Control Method } \\
\hline & \multicolumn{8}{|c|}{ Biopesticides } & \multirow{2}{*}{\multicolumn{2}{|c|}{$\begin{array}{l}\text { Resistant } \\
\text { Varieties }\end{array}$}} & \multirow{2}{*}{\multicolumn{2}{|c|}{ Cultural Control }} & \multirow{2}{*}{\multicolumn{2}{|c|}{$\begin{array}{c}\text { Synthetic } \\
\text { Pesticides } \\
(-)\end{array}$}} \\
\hline & \multicolumn{2}{|l|}{ EPF } & \multicolumn{2}{|c|}{ Bacteria } & \multicolumn{2}{|c|}{ Viruses } & \multicolumn{2}{|l|}{$\begin{array}{l}\text { Botanical } \\
\text { Pesticides }\end{array}$} & & & & & & \\
\hline & AF & MV & AF & MV & AF & MV & AF & MV & AF & MV & AF & MV & AF & MV \\
\hline Predators & $\begin{array}{c}(+) \\
{[145,148,149]}\end{array}$ & $(*)$ & $(*)$ & $\left({ }^{*}\right)$ & $(*)$ & $\left(^{*}\right)$ & $\begin{array}{c}(+) \\
{[21,65,124,125]}\end{array}$ & $(*)$ & $\begin{array}{c}(+) \\
{[189]}\end{array}$ & $\left({ }^{*}\right)$ & $\begin{array}{c}(+) \\
{[131,200]}\end{array}$ & $\begin{array}{c}(+) \\
{[131]}\end{array}$ & $\begin{array}{c}(-) \\
{[65,124,125]}\end{array}$ & $(*)$ \\
\hline Parasitoids & $\begin{array}{c}(+) \\
{[150]}\end{array}$ & $(*)$ & $(*)$ & $\left(^{*}\right)$ & $\left.{ }^{*}\right)$ & $\begin{array}{c}(+) \\
{[145]}\end{array}$ & $\begin{array}{c}(+) \\
{[150]}\end{array}$ & $(*)$ & $\left(^{*}\right)$ & $\left(^{*}\right)$ & $\left(^{*}\right)$ & $\begin{array}{c}(+) \\
{[185]}\end{array}$ & $(*)$ & $(*)$ \\
\hline
\end{tabular}

Note: $(+)$ shows compatibility; $(-)$ shows non-compatibility; $\left({ }^{*}\right)$ implies the compatibility is less-studied.

Additionally, the incorporation of biological control into management strategies for smallholders is exacerbated by low levels of experience, expertise, and broader knowledge about the natural enemies among smallholder farmers and their requirements, especially how landscapes can influence the abundance and diversity of biological control species. In some cases, the species that support beneficial insects may also provide botanical pesticides, such as Tephrosia vogelii, Annona muricata, and Piper guineense, and a combination of control options with biological control have shown potential in decreasing $M$. vitrata and A. fabae infestations while achieving high yields compared with synthetic pesticides [170,172,191]. However, the yield data for different management options are also lacking, and therefore, it is of importance to address this gap. The synergistic effects of $M$. vitrata and A. fabae control are exhibited when some biopesticides are used with natural enemies. Therefore, more studies should focus on different biopesticides and their compatibility with natural enemies for increasing the efficacy in the management of $A$. fabae and M. vitrata. The use of IPM has been advocated in the literature as a solution to sustainably managing pests for years [201,202], but the implementation still requires work and, in particular, more compatibility studies.

A combination of strategies such as the cultural control, application of biopesticides, and using resistant varieties with the efficient monitoring of pests could work together with natural enemies to bring about the effective management of $M$. vitrata. Some works have reported an increasing control efficiency when a combination of strategies such as resistant cowpea varieties; cultural methods (manipulating of the planting date, adjusting planting spacing, and using mixed cropping); and the reduced application of synthetic pesticides with natural enemies was used in IPM $[36,137,203,204]$. One challenge that limits the efficacy of using a cultural control is its dependence on seasons and locations. Additionally, the lack of sources of resistance traits has limited the development of some resistant varieties for $M$. vitrata and $A$. fabae. The use of resistant varieties and cultural control could 
help in enhancing the efficacy of M. vitrata and A. fabae controls, and thus, more studies should explore the control of these pests by using biological controls with resistant varieties and cultural control efficacy to minimize the losses by M. vitrata and A. fabae.

This literature review discussed biological control as a feasible IPM strategy for smallholder farmers of SSA. The evidence indicates a considerable potential in employing available plant diversities from farmers' localities to manage pests while enhancing the populations of natural enemies for M. vitrata and A. fabae management. This form of NPR is also compatible with other control strategies, such as biopesticides, cultural control, and the use of resistant crop varieties. However, the use of biopesticides requires more investment in their development and efficacy in controlling M. vitrata and A. fabae. Equally, more work is needed in developing resistant varieties for $M$. vitrata and A. fabae; some of the identified varieties for controlling $M$. vitrata and $A$. fabae in the surveyed literature have been found to exhibit a moderate resistance to $M$. vitrata and A. fabae. The use of cultural control for $M$. vitrata has shown inconsistent results, and thus, there is a need to generate more knowledge on the limitations and potential of this approach as part of an integrated system.

A community-based approach to implementing different management alternatives, such as the growth/preparation of PBPs, the production of EPF/viruses at a community level, or the knowledge exchange among smallholder farmers about natural enemies, would help to overcome some of these issues $[15,64,205]$. The training and capacity building of farmers could also facilitate a better understanding of biological control and its compatibility with other control strategies for enhancing the ecosystem services provided by natural enemies. The information reviewed here informs how biological control is a key component in the sustainable management of $A$. fabae and $M$. vitrata and how it interacts with other sustainable approaches to the management network of key bean pests. More knowledge should be generated on the importance of a system-based ecological approach to increase the understanding of the management options.

Author Contributions: S.R.B., P.C.S., E.R.M., V.C.W., S.E.J.A. and P.A.N. reviewed and edited the manuscript. B.J.N. prepared and wrote the manuscript. All authors have read and agreed to the published version of the manuscript.

Funding: The funding for this work was received from the UKRI GCRF project: Natural Pest Regulation in Orphan Crop Legumes in Africa (NaPROCLA) to P.C.S., S.R.B. and S.E.J.A., grant number BB/R020361/1.

Institutional Review Board Statement: Not applicable.

Informed Consent Statement: Not applicable.

Data Availability Statement: Not applicable.

Conflicts of Interest: The authors declare that they have no conflict of interest.

\section{References}

1. FAO; IFAD; UNICEF; WFP; WHO. The State of Food Security and Nutrition in the World 2020: Transforming Food Systems for Affordable Healthy Diets; FAO: Rome, Italy, 2020.

2. Hillocks, R.J.; Madata, C.S.; Chirwa, R.; Minja, E.M.; Msolla, S. Phaseolus bean improvement in Tanzania, 1959-2005. Euphytica 2006, 150, 215-231. [CrossRef]

3. OECD (Organisation for Economic Co-operation and Development); Food and Agriculture Organization (FAO). OECD-FAO Agricultural Outlook 2016-2025; OECD Publishing: Paris, France, 2016.

4. Ricciardi, V.; Wane, A.; Sidhu, B.S.; Godde, C.; Solomon, D.; McCullough, E.; Diekmann, F.; Porciello, J.; Jain, M.; Randall, N.; et al. A scoping review of research funding for small-scale farmers in water-scarce regions. Nat. Sustain. 2020, 3, 836-844. [CrossRef]

5. Vanlauwe, B.; Coyne, D.; Gockowski, J.; Hauser, S.; Huising, J.; Masso, C.; Nziguheba, G.; Schut, M.; Van Asten, P. Sustainable intensification and the African smallholder farmer. Curr. Opin. Environ. Sustain. 2014, 8, 15-22. [CrossRef]

6. $\quad$ Broughton, W.J.; Hernandez, G.; Blair, M.; Beebe, S.; Gepts, P.; Vanderleyden, J. Beans (Phaseolus spp.)-model food legumes. Plant Soil 2003, 252, 55-128. [CrossRef] 
7. Nedumaran, S.; Abinaya, P.; Jyosthnaa, P.; Shraavya, B.; Rao, P.P.; Bantilan, M.C.S. Grain Legumes Production, Consumption and Trade Trends in developing Countries; Markets, Institutions and Policies 64 Working Paper Series No 60. ICRISAT Research Program, Markets, Institutions and Policies; International Crops Research Institute for the Semi-Arid Tropics: Patancheru, Telangana, India, 2015; p. 64.

8. Katungi, E.; Farrow, A.; Mutuoki, T.; Gebeyehu, S.; Karanja, D.; Alamayehu, F.; Sperling, L.; Beebe, S.; Rubyogo, J.C.; Buruchara, R. Improving Common Bean Productivity: An Analysis of Socioeconomic Factors in Ethiopia and Eastern Kenya. Baseline Rep. Trop. legumes II; Centro Internacional de Agricultura Tropical-CIAT: Cali, Colombia, 2010.

9. Otieno, M.; Steffan-Dewenter, I.; Potts, S.G.; Kinuthia, W.; Kasina, M.J.; Garratt, M.P.D. Enhancing legume crop pollination and natural pest regulation for improved food security in changing African landscapes. Glob. Food Secur. 2020, 26, 100394. [CrossRef]

10. van Loon, M.P.; Deng, N.; Grassini, P.; Rattalino Edreira, J.I.; Wolde-meskel, E.; Baijukya, F.; Marrou, H.; van Ittersum, M.K. Prospect for increasing grain legume crop production in East Africa. Eur. J. Agron. 2018, 101, 140-148. [CrossRef]

11. Allen, D.J. Pests, Diseases, and Nutritional Disorders of the Common Bean in Africa: A Field Guide (No. 260); CIAT: Cali, Colombia, 1996.

12. da Silva, A.G.; Junior, A.L.B.; da Silva Farias, P.R.; de Souza, B.H.S.; Rodrigues, N.E.L.; Carbonell, S.A.M. Common bean resistance expression to whitefly in winter and rainy seasons in Brazil. Sci. Agric. 2019, 76, 389-397. [CrossRef]

13. Muimba-Kankolongo, A. Food Crop Production by Smallholder Farmers in Southern Africa: Challenges and Opportunities for Improvement; Academic Press: Cambridge, MA, USA, 2018. [CrossRef]

14. Nyamwasa, I.; Li, K.; Rutikanga, A.; Rukazambuga, D.N.T.; Zhang, S.; Yin, J.; Ya-Zhong, C.; Zhang, X.X.; Sun, X. Soil insect crop pests and their integrated management in East Africa: A review. Crop. Prot. 2018, 106, 163-176. [CrossRef]

15. Belmain, S.R.; Haggar, J.; Holt, J.; Stevenson, P.C. Managing Legume Pests in Sub-Saharan Africa: Challenges and Prospects for Improving Food Security and Nutrition through Agroecological Intensification; Natural Resources Institute, University of Greenwich: Chatham Maritime, UK, 2013; p. 34.

16. Rice, P.J.; Arthur, E.L.; Barefoot, E.C. Advances on environmental fate and exposures assessments. J. Agric. Food Chem. 2007, 55, 5367-5376. [CrossRef]

17. El-Heneidy, A.H.; Khidr, A.A.; Taman, A.A. Side-effects of insecticides on non-target organisms: 1-In Egyptian cotton fields. Int. Med. J. 2015, 25, 685-690.

18. Bora, D.; Khanikor, B.; Gogoi, H. Plant-based pesticides: Green environment with special reference to silk worms. Pestic. Adv. Chem. Bot. Pestic. 2012, 8, 171-206. [CrossRef]

19. Gurr, G.M.; Reynolds, O.L.; Johnson, A.C.; Desneux, N.; Zalucki, M.P.; Furlong, M.J.; Li, Z.; Akutse, K.S.; Chen, J.; Gao, X.; et al. Landscape ecology and expanding range of biocontrol agent taxa enhance prospects for diamondback moth management. $A$ review. Agron. Sustain. Dev. 2018, 38, 1-16. [CrossRef]

20. Gurr, G.M.; Wratten, S.D.; Landis, D.A.; You, M. Habitat management to suppress pest populations: Progress and prospects. Annu. Rev. Entomol. 2017, 62, 91-109. [CrossRef]

21. Stevenson, P.C.; Isman, M.B.; Belmain, S.R. Pesticidal plants in Africa: A global vision of new biological control products from local uses. Ind. Crop. Prod. 2017, 110, 2-9. [CrossRef]

22. Anyanga, M.O.; Yada, B.; Yencho, G.C.; Ssemakula, G.N.; Alajo, A.; Farman, D.I.; Mwanga, R.O.; Stevenson, P.C. Segregation of hydroxycinnamic acid esters mediating sweet potato weevil resistance in storage roots of sweet potato. Front. Plant Sci. 2017, 8, 1011. [CrossRef]

23. Miller, J.R.; Gut, L.J. Mating disruption for the 21st century: Matching technology with mechanism. Environ. Entomol. 2015, 44, 427-453. [CrossRef] [PubMed]

24. Karungi, J.; Adipala, E.; Kyamanywa, S.; Ogenga-Latigo, M.W.; Oyobo, N.; Jackai, L.E.N. Pest management in cowpea. Part 2. Integrating planting time, plant density, and insecticide application for management of cowpea field insect pests in eastern Uganda. Crop. Prot. 2000, 19, 237-245. [CrossRef]

25. Karel, A.K.; Autrique, A. Insects and other pests in Africa. In Bean Production Problems in the Tropics, 2nd ed.; Schwarts, H.F., Pastor-Corrales, M.A., Eds.; Centro Internacional de Agricultura Tropical (CIAT): Cali, Colombia, 1989; pp. 455-504.

26. Abate, T.; Ampofo, J.K.O. Insect pests of beans in Africa: Their ecology and management. Annu. Rev. Entomol. 1996, 41, 45-73. [CrossRef]

27. Swaine, G. Studies on the biology and control of pests of seed beans (Phaseolus vulgaris) in northern Tanzania. Bull. Entomol. Res. 1969, 59, 323-338. [CrossRef]

28. Nyiira, Z.M. Pests of grain legumes and their control in Uganda: In Pest. of Grain Legumes: Ecology and Control; Taylor, T.A., Singh, S.R., van Emden, H.F., Eds.; Academic Press: London, UK, 1978; pp. 118-121.

29. Karel, A.K. Yield losses from and control of bean pod borers, Maruca testulalis (Lepidoptera: Pyralidae) and Heliothis armigera (Lepidoptera: Noctuidae). J. Econ. Entomol. 1985, 78, 1323-1326. [CrossRef]

30. De Lima, C.P.F. Management of pests of subsistence crops. In Pest and Vector Management in the Tropics; Youdowei, A., Service, M.W., Eds.; Longman: London, UK, 1983.

31. Sharma, H.C. Bionomics, host plant resistance, and management of the legume pod borer, Maruca vitrata-A review. Crop. Prot. 1998, 73, 373-386. [CrossRef]

32. Jayasinghe, R.C.; Premachandra, W.D.; Neilson, R. A study on Maruca vitrata infestation of Yard-long beans (Vigna unguiculata subspecies sesquipedalis). Heliyon 2015, 1, e00014. [CrossRef] 
33. Liao, C.T.; Lin, C.S. Occurrence of the legume pod borer, Maruca testulalis Geyer (Lepidoptera: Pyralidae) on cowpea (Vigna unguiculata Walp) and its insecticides application trial. Plant Prot. Bull. 2000, 42, 213-222.

34. Margam, V.; Coates, B.; Bayles, D.; Hellmich, R.; Agunbiade, T.; Seufferheld, M.; Sun, W.; Kroemer, J.; Ba, M.; Binso-Dabiré, C.; et al. Transcriptome sequencing, and rapid development and application of snp markers for the legume pod borer, Maruca vitrata (Lepidoptera: Crambidae). PLoS ONE 2011, 6, e21388. [CrossRef] [PubMed]

35. Wamonje, F.O.; Donnelly, R.; Tungadi, T.D.; Murphy, A.M.; Pate, A.E.; Woodcock, C.; Caulfield, J.; Mutuku, J.M.; Bruce, T.J.A.; Gilligan, C.A.; et al. Different plant viruses induce changes in feeding behavior of specialist and generalist aphids on common bean that are likely to enhance virus transmission. Front. Plant Sci. 2020, 10, 1-13. [CrossRef] [PubMed]

36. Jackai LE, N. Integrated pest management of borers of cowpea and beans. Int. J. Trop. Insect Sci. 1995, 16, 237-250. [CrossRef]

37. Abate, T.; Van Huis, A.; Ampofo, J.K.O. Pest management strategies in traditional agriculture: An African perspective. Annu. Rev. Entomol. 2000, 45, 631-659. [CrossRef]

38. Atachi, P.; Djihou, Z. Record of host-plants of Maruca testulalis (Geyer) (Lepidoptera: Pyralidae) in the Republic of Benin. Ann. Soc. Entomol. Fr. 1994, 30, 169-174.

39. Capinera, J.L. Order Homoptera-aphids, leaf-and planthoppers, psyllids and whiteflies. In Handbook of Vegetable Pests, 1st ed.; Academic Press: San Diego, CA, USA, 2001; pp. 279-282.

40. Margam, V.M.; Baoua, I.; Ba, N.M.; Ishiyaku, M.F.; Huesing, J.E.; Pittendrigh, B.R.; Murdock, L.L. Wild host plants of legume pod borer Maruca vitrata (Lepidoptera: Pyraloidea: Crambidae) in southern Niger and northern Nigeria. Int. J. Trop. Insect Sci. 2010, 30, 108-114. [CrossRef]

41. Jackai, L.E.N. Efficacy of insecticide applications at different times of day against the legume pod-borer, Maruca testulalis (Geyer) (Lepidoptera: Pyralidae), on cowpea in Nigeria. Prot. Ecol. 1983, 5, 245-251.

42. Baoua, I.; Ba, N.M.; Agunbiade, T.A.; Margam, V.; Binso-Dabiré, C.L.; Antoine, S.; Pittendrigh, B.R. Potential use of Sesbania pachycarpa (Fabaceae: Papilionoideae) as refugia for the legume pod borer Maruca vitrata (Lepidoptera: Crambidae). Int. J. Trop. Insect Sci. 2011, 31, 12-218. [CrossRef]

43. Larocca, A.; Fanti, P.; Molinaro, A.; Mattia, M.F.; Battaglia, D. Aphid performance on Vicia faba and two southern Italy Phaseolus vulgaris landraces. Bull. Insectology 2011, 64, 101-106.

44. Adabi, S.T.; Talebi, A.A.; Fathipour, Y.; Zamani, A.A. Life history and demographic parameters of Aphis fabae (Hemiptera: Aphididae) and its parasitoid, Aphidius matricariae (Hymenoptera: Aphidiidae) on four sugar beet cultivars. Acta Entomol. Serbica 2010, 15, 61-73.

45. Ehler, L.E.; Long, R.F.; Kinsey, M.G.; Kelley, S.K. Potential for augmentative biological control of black bean aphid in California sugarbeet. Entomophaga 1997, 42, 241. [CrossRef]

46. Blackman, R.L.; Eastop, V.F. Aphids on the World's Crops: An Identification and Information Guide, 2nd ed.; John Wiley \& Sons: Chichester, UK, 2000.

47. Abtew, A.; Niassy, S.; Affognon, H.; Subramanian, S.; Kreiter, S.; Garzia, G.T.; Martin, T. Farmers' knowledge and perception of grain legume pests and their management in the Eastern province of Kenya. Crop. Prot. 2016, 87, 90-97. [CrossRef]

48. Sampaio, M.V.; Bueno VH, P.; Silveira LC, P.; Auad, A.M. Biological control of insect pests in the tropics. In Tropical Biology and Conservation Management; Del Claro, K., Oliveira, P.S., Rico-Gray, V., Eds.; Eolss Publishers: Oxford, UK, 2009 ; pp. 28-70.

49. Ehler, L.E. Integrated pest management (IPM): Definition, historical development and implementation, and the other IPM. Pest. Manag. Sci. 2006, 62, 787-789. [CrossRef] [PubMed]

50. Crowder, D.W.; Jabbour, R. Relationships between biodiversity and biological control in agroecosystems: Current status and future challenges. Biol. Control 2014, 75, 8-17. [CrossRef]

51. Nilsson, U.; Porcel, M.; Świergiel, W.; Wivstad, M. Habitat Manipulation-As a Pest. Management Tool in Vegetable and Fruit Cropping Systems, with the Focus on Insects and Mites; SLU, EPOK-Centre for Organic Food \& Farming: Uppsala, Sweden, 2016 ; p. 52.

52. Cock, M.; Lenteren, J.C.; Brodeur, J.; Barratt, B.; Bigler, F.; Bolckmans, K.; Cônsoli, F.L.; Haas, F.; Mason, P.; Parra, J. Do new access, and benefit-sharing procedures under the convention on biological diversity threaten the future of biological control? BioControl 2009, 55, 199-218. [CrossRef]

53. Jacas, J.A.; Urbaneja, A. Biological control in citrus in Spain: From classical to conservation biological control. In Integrated Management of Arthropod Pests and Insect-Borne Diseases; Springer: Dordrecht, The Netherlands, 2010; pp. 61-72. [CrossRef]

54. van Lenteren, J.C. The state of commercial augmentative biological control: Plenty of natural enemies, but a frustrating lack of uptake. Biol. Control 2012, 57, 1-20. [CrossRef]

55. van Lenteren, J.C.; Bolckmans, K.; Köhl, J.; Ravensberg, W.J.; Urbaneja, A. Biological control using invertebrates and microorganisms: Plenty of new opportunities. BioControl 2018, 63, 39-59. [CrossRef]

56. Girma, H.; Rao, M.R.; Sithanantham, S. Insect pests and beneficial hedgerow intercropping systems in semiarid Kenya. Agrofor. Syst. 2000, 50, 279-292. [CrossRef]

57. Mkenda, P.A.; Ndakidemi, P.A.; Mbega, E.; Stevenson, P.C.; Arnold SE, J.; Gurr, G.M.; Belmain, S.R. Multiple ecosystem services from field margin vegetation for ecological sustainability in agriculture: Scientific evidence and knowledge gaps. Peer J 2019, 11, 1-33. [CrossRef]

58. Mkenda, P.A.; Ndakidemi, P.A.; Stevenson, P.C.; Sarah, S.E.; Belmain, S.R.; Chidege, M.; Gurr, G.M. Field margin vegetation in tropical African bean systems harbours diverse natural enemies for biological pest control in adjacent crops. Sustainability 2019, 11, 6399. [CrossRef] 
59. Asif, S.; Saeed, S. Floral host plant range of syrphid flies (Syrphidae: Diptera) under natural conditions in southern Punjab, Pakistan. Pak. J. Bot. 2010, 42, 1187-1200.

60. Colley, M.R.; Luna, J.M. The relative attractiveness of potential beneficial insectary plants to aphidophagous hoverflies (Diptera: Syrphidae). Environ. Entomol. 2000, 29, 1054-1059. [CrossRef]

61. Hatt, S.; Lopes, T.; Boeraeve, F.; Chen, J.; Francis, F. Pest regulation and support of natural enemies in agriculture: Experimental evidence of within field wildflower strips. Ecol. Eng. 2017, 98, 240-245. [CrossRef]

62. Hatt, S.; Mouchon, P.; Lopes, T.; Francis, F. Effects of wildflower strips and an adjacent forest on aphids and their natural enemies in a pea field. Insects 2017, 8, 99. [CrossRef]

63. Martini, X.; Pelz-Stelinski, K.S.; Stelinski, L.L. Plant pathogen-induced volatiles attracts parasitoids to increase the parasitism of an insect vector. Front. Ecol. Evol. 2014, 2,1-8. [CrossRef]

64. Mkenda, P.A.; Ndakidemi, P.A.; Stevenson, P.C.; Arnold SE, J.; Darbyshire, I.; Belmain, S.R.; Priebe, J.; Johnson, A.C.; Tumbo, J.; Gurr, G.M. Knowledge gaps among smallholder farmers hinder the adoption of conservation biological control. Biocontrol Sci. Technol. 2020, 30, 256-277. [CrossRef]

65. Mkenda, P.; Mwanauta, R.; Stevenson, P.C.; Ndakidemi, P.; Mtei, K.; Belmain, S.R. Extracts from field margin weeds provide economically viable and environmentally benign pest control compared to synthetic pesticides. PLoS ONE 2015, 10, 1-14. [CrossRef]

66. Okeyo-Owuor, J.B.; Oloo, G.W.; Agwaro, P.O. Natural enemies of the legume pod borer, Maruca testulalis Geyer (Lepidoptera: Pyralidae) in small-scale farming systems of Western Kenya. Int. J. Trop. Insect Sci. 1991, 12, 35-42. [CrossRef]

67. Arodokoun, D.Y. Importance of Plants-Alternative Hosts and Indigenous Natural Enemies in the Biological Control of Maruca testulalis Geyer (Lepidoptera: Pyralidae), a Pest of Vigna Unguiculata Walp. Ph.D. Thesis, Laval University, Quebec, QC, Canada, 1991.

68. Arodokoun, D.Y.; Tamo, M.; Cloutier, C.; Brodeur, J. Larval parasitoids occurring on Maruca vitrata Fabricius (Lepidoptera: Pyralidae) in Benin, West Africa. Agric. Ecosyst. Environ. 2006, 113, 320-325. [CrossRef]

69. Dannon, E.A.; Tamò, M.; Agboton, C.; van Huis, A.; Dicke, M. Effect of Maruca vitrata (Lepidoptera: Crambidae) host plants on life-history parameters of the parasitoid Apanteles taragamae (Hymenoptera). Insect Sci. 2012, 19, 518-528. [CrossRef]

70. Huang, C.C.; Peng, W.K.; Talekar, N.S. Parasitoids and other natural enemies of Maruca vitrata feeding on Sesbania cannabina in Taiwan. Biol. Control. 2003, 48, 407-416. [CrossRef]

71. Van Halteren, P. A code of conduct for the import and release of exotic biological control agents for Europe? EPPO Bull. 1997, 27, 45-48. [CrossRef]

72. Yule, S.; Srinivasan, R. Combining bio-pesticides with chemical pesticides to manage legume pod borer (Maruca vitrata) on yard-long bean in Thailand. Int. J. Pest. Manag. 2014, 60, 67-72. [CrossRef]

73. Souna, D.A.; Bokonon-Ganta, A.H.; Dannon, E.A.; Imorou, N.; Agui, B.; Cusumano, A.; Srinivasan, R.; Pittendrigh, B.R.; Volkoff, A.N.; Tamò, M. Volatiles from Maruca vitrata (Lepidoptera, Crambidae) host plants influence olfactory responses of the parasitoid, Therophilus javanus (Hymenoptera: Hymenoptera). Biol. Control 2019, 130, 104-109. [CrossRef]

74. Souza AR de Giustolin, T.A.; Querino, R.B.; Alvarenga, C.D. Natural parasitism of Lepidopteran eggs by Trichogramma species (Hymenoptera: Trichogrammatidae) in agricultural crops in Minas Gerais, Brazil. Fla. Entomol. 2016, 99, 221-225. [CrossRef]

75. Huis, A.V.a.n.; Dicke, M. Functional response and life history parameters of Apanteles taragamae, a larval parasitoid of Maruca vitrata. Biol. Control 2010, 55, 363-378. [CrossRef]

76. Albajes, R.; Gullino, M.L.; van Lenteren, J.C.; Elad, Y. (Eds.) Integrated Pest and Disease Management in Greenhouse Crops; Kluwer Academic Publishers: Dordrecht, Netherlands, 1999.

77. Farhadi, R.; Allahyari, H.; Chi, H. Life table and predation capacity of Hippodamia variegata (Coleoptera: Coccinellidae) feeding on Aphis fabae (Hemiptera: Aphididae). Biol. Control 2011, 59, 83-89. [CrossRef]

78. Farhadi, R.; Allahyari, H.; Juliano, S.A. The functional response of larval and adult stages of Hippodamia variegata (Coleoptera: Coccinellidae) to different densities of Aphis fabae (Hemiptera: Aphididae). Environ. Entomol. 2010, 39, 1586-1592. [CrossRef]

79. Franzman, B.A. Hippodamia variegata, a predacious ladybird new in Australia. Aust. J. Entomol. 2002, 41, 375-377. [CrossRef]

80. Kontodimas, D.C.; Stathas, G.J. Phenology fecundity and life table parameters of the predator Hippodamia vagriegata reared on Dyaphis crataegi. Biol. Control 2005, 50, 223-233. [CrossRef]

81. Balog, A.; Mehrparvar, M.; Weisser, W.W. Polyphagous predatory rove beetles (Coleoptera: Staphylinidae) induce winged: Morphs in the pea aphid Acyrthosiphon pisum (Hemiptera: Aphididae). Eur. J. Entomol. 2013, 110, 153-157. [CrossRef]

82. Banks, C.J. Effects of insect predators on small populations of Aphis fabae in the field. Entomol. Exp. Appl. 1968, 11, 169-176. [CrossRef]

83. Nordey, T.; Boni, S.B.; Agbodzavu, M.K.; Mwashimaha, R.; Mlowe, N.; Ramasamy, S.; Deletre, E. Comparison of biological methods to control Aphis fabae Scopoli (Hemiptera: Aphididae) on kalanchoe crops in East Africa. Crop. Prot. 2021, 142, 105520. [CrossRef]

84. Solomon, M.G.; Cross, J.V.; Fitzgerald, J.D.; Campbell CA, M.; Jolly, R.L.; Olszak, R.W.; Niemczyk, E.; Vogt, H. Biocontrol of pests of apples and pears in northern and central Europe-3. Predators. Biocontrol Sci. Technol. 2000, 10, 91-128. [CrossRef]

85. Patterson, R.; Ramirez, R. Aphid Natural Enemies and Biological Control. Utah State University Extension. Available online: https:/ /digitalcommons.usu.edu/extension_curall/814 (accessed on 22 June 2020). 
86. Nyukuri, R.W.; Kirui, S.C.; Wanjala FM, E.; Odhiambo, J.O.; Cheramgoi, E. The effectiveness of coccinellids as natural enemies of aphids in maize, beans and cowpeas intercrop. J. Agric. Sci. Technol. 2012, 2, 1003-1010.

87. Twardowski, J.P.; Hurej, M.; Klukowski, Z. The effect of the strip-management on reduction of Aphis fabae (Homoptera: Aphididae) populations by predators on sugar beet crop. J. Plant. Prot. Res. 2005, 45, 3.

88. Mkenda, P.A.; Ndakidemi, P.A.; Stevenson, P.C.; Arnold, S.E.; Belmain, S.R.; Chidege, M.; Gurr, G.M.; Woolley, V.C. Characterization of hymenopteran parasitoids of Aphis fabae in an African smallholder bean farming system through sequencing of COI 'Mini-barcodes'. Insects 2019, 10, 331. [CrossRef] [PubMed]

89. Völkl, W.; Stechmann, D.H. Parasitism of the black bean aphid (Aphis fabae) by Lysiphlebus fabarum (Hym., Aphidiidae): The influence of host plant and habitat. J. Appl. Entomol 1998, 122, 201-206. [CrossRef]

90. Zamani, A.; Talebi, A.; Fathipour, Y.; Baniameri, V. The temperature-dependent functional response of two aphid parasitoids, Aphidius colemani and Aphidius matricariae (Hymenoptera: Aphidiidae), on the cotton aphid. J. Pest. Sci. 2006, 79, 183-188. [CrossRef]

91. Sampaio, M.V.; Bueno VH, P.; da Conceicao de Menezes Soglia, M.; De Conti, B.F.; Rodrigues, S.M.M. Larval competition between Aphidius colemani and Lysiphlebus testaceipes after multiparasitism of the host Aphis gossypii. Bull. Insectology 2006, $59,147$.

92. Landis, D.A.; Wratten, S.D.; Gurr, G.M. Habitat management to conserve natural enemies of arthropod pests in agriculture. Annu. Rev. Entomol. 2000, 45, 175-201. [CrossRef]

93. Lundgren, J.G. Relationships of Natural Enemies and Non-Prey Foods; Springer: Dordrecht, The Netherlands, 2009.

94. Gurr, G.M.; Wratten, S.D.; Altieri, M.A. Ecological engineering: A new direction for agricultural pest management. AFBM J. 2004, 1, 28-35. [CrossRef]

95. Wäckers, F.L.; van Rijn, P.C.J. Food for protection: An introduction. In Plant-Provided Food for Carnivorous Insects: A Protective Mutualism and Its Applications; Wäckers, F.L., van Rijn, P.C.J., Bruin, J., Eds.; Cambridge University Press: Cambridge, UK, 2005; pp. 1-14.

96. Wäckers, F.L.; Van Rijn, P.C.J. Pick and mix: Selecting flowering plants to meet the requirements of target biological control insects. In Biodiversity and Insect Pests: Key Issues for Sustainable Management; Gurr, G.M., Wratten, S.D., Snyder, W.E., Read, D.M.Y., Eds.; John Wiley \& Sons, Ltd.: Chichester, UK, 2012; pp. 139-165.

97. Philips, C.R.; Rogers, M.A.; Kuhar, T.P. Understanding farmscapes and their potential for improving IPM programs. J. Integr. Pest Manag. 2014, 5, 1-9. [CrossRef]

98. FAO. Organic Agriculture: Glossary on Organic Agriculture; FAO: Rome, Italy, 2009; pp. 1-173.

99. Rahat, S.; Gurr, G.M.; Wratten, S.D.; Mo, J.; Neeson, R. Effect of plant nectars on adult longevity of the stinkbug parasitoid, Trissolcus basalis. Int. J. Pest. Manag. 2005, 51, 321-324. [CrossRef]

100. Saidov, N.S.; Douglas, L.A. Evaluation of flowering plants to attract natural enemies in Tajikistan. In Proceedings of the Conference Devoted to 50 Years Kazakh Research Institute of Plant Protection and Quarantine, Almaty, Kazakhstan, November 2008; Volume 1, pp. 127-132.

101. Albrecht, M.; Kleijn, D.; Williams, N.; Tschumi, M.; Blaauw, B.; Bommarco, R.; Campbell, A.J.; Dainese, M.; Drummond, F.; Entling, M.; et al. The effectiveness of flower strips and hedgerows on pest control, pollination services and crop yield: A quantitative synthesis. Ecol. Lett. 2020, 23, 1488-1498. [CrossRef] [PubMed]

102. Wäckers, F.L.; Romeis, J.; van Rijn, P. Nectar and pollen feeding by insect herbivores and implications for multitrophic interactions. Annu. Rev. Entomol. 2007, 52, 301-323. [CrossRef]

103. Winkler, K.; Wäckers, F.L.; Termorshuizen, A.J.; van Lenteren, J.C. Assessing risks and benefits of floral supplements in conservation biological control. Biol. Control. 2010, 55, 719-727. [CrossRef]

104. Karp, D.S.; Chaplin-Kramer, R.; Meehan, T.D.; Martin, E.A.; DeClerck, F.; Grab, H.; Gratton, C.; Hunt, L.; Larsen, A.E.; MartínezSalinas, A.; et al. Crop pests and predators exhibit inconsistent responses to surrounding landscape composition. Proc. Natl. Acad. Sci. USA 2018, 115, E7863-E7870. [CrossRef]

105. Gonçalves, P.A.D.S.; Sousa e Silva, C.R. Efeito de espécies vegetais em bordadura em cebola sobre a densidade populacional de tripes e sirfídeos predadores. Hortic. Bras. 2003, 21, 731-733. [CrossRef]

106. Jado, R.H.; Araj, S.E.; Abu-Irmaileh, B.; Shields, M.W.; Wratten, S.D. Floral resources to enhance the potential of the parasitoid, Aphidius colemani for biological control of the aphid, Myzus persicae. J. Appl. Entomol. 2019, 143, 34-42. [CrossRef]

107. Pfiffner, L.; Luka, H.; Schlatter, C.; Juen, A.; Traugott, M. Impact of wildflower strips on biological control of cabbage lepidopterans. Agric. Ecosyst. Environ. 2009, 129, 310-314. [CrossRef]

108. Pfiffner, L.; Luka, H.; Schlatter, M.; Lichtenhahn, M. Wildflower strips to reduce lepidopteran pests in cabbage crops. In Landscape management for functional biodiversity. IOBC/WPRS Bull. 2006, 29, 97-99.

109. Zhu, P.; Wang, G.; Zheng, X.; Tian, J.; Lu, Z.; Heong, K.L.; Xu, H.; Chen, G.; Yang, Y.; Gurr, G.M. Selective enhancement of parasitoids of rice Lepidoptera pests by sesame (Sesamum indicum) flowers. Biol. Control. 2014, 60, 157-167. [CrossRef]

110. Sujayanand, G.K.; Chandra, A.; Pandey, S.; Bhatt, S. Seasonal abundance of spotted pod borer, Maruca vitrata Fabricius in early pigeon pea [Cajanus cajan (L.) millsp.] and its management through farmscaping in Uttar Pradesh. Legume Res. 2021, 44, $233-239$. [CrossRef]

111. Allmann, S.; Späthe, A.; Bisch-Knaden, S.; Kallenbach, M.; Reinecke, A.; Sachse, S.; Baldwin, I.T.; Hansson, B.S. Feeding-induced rearrangement of green leaf volatiles reduces moth oviposition. eLife 2013, 2, e00421. [CrossRef] [PubMed] 
112. Pichersky, E.; Gershenzon, J. The formation and function of plant volatiles: Perfumes for pollinator attraction and defense. Curr. Opin. Plant Biol. 2002, 5, 237-243. [CrossRef]

113. Dudareva, N.; Negre, F.; Nagegowda, D.A.; Orlova, I. Plant volatiles: Recent advances and future perspectives. Crit. Rev. Plant Sci. 2006, 25, 417-440. [CrossRef]

114. Khan, Z.R.; James, D.G.; Midega CA, O.; Pickett, J.A. Chemical ecology and conservation biological control. Biol. Control. 2008, 45, 210-224. [CrossRef]

115. Kaplan, I. Attracting carnivorous arthropods with plant volatiles: The future of biocontrol or playing with fire? Biol. Control. 2012, 60, 77-89. [CrossRef]

116. Agbessenou, A.; Tounou, A.K.; Dannon, E.A.; Datinon, B.; Agboton, C.; Ramasamy, S.; Pittendrigh, B.R.; Tamò, M. The parasitic fly Nemorilla maculosa exploits host-plant volatiles to locate the legume pod borer, Maruca vitrata. Entomol. Exp. Appl. 2018, 166, 673-682. [CrossRef]

117. Rashedi, A.; Rajabpour, A.; Rasekh, A.; Zandi-Sohani, N. Interactions between host plant, Aphis fabae, and its natural enemies, Orius albidipennis and Lysiphlebus fabarum in a tri-trophic system. J. Asia-Pac. Entomol. 2019, 22, 847-852. [CrossRef]

118. Osei-Owusu, J.; Vuts, J.; Caulfield, J.C.; Woodcock, C.M.; Withall, D.M.; Hooper, A.M.; Osafo-Acquaah, S.; Birkett, M.A. Identification of Semiochemicals from cowpea, Vigna unguiculata, for low-input management of the legume pod borer, Maruca vitrata. J. Chem. Ecol. 2020, 46, 288-298. [CrossRef] [PubMed]

119. Ajayi, C.O.; Aknnifesi, K.F. Farmers' understanding of pesticide safety labels and field spraying practices: A case study of cotton farmers. Sci. Res. Essay 2007, 2, 204-210.

120. Nonga, H.E.; Mdegela, R.H.; Lie, E.; Sandvik, M. Assessment of farming practices and uses of agrochemicals in Lake Manyara basin, Tanzania. Afr. J. Agric. Res. 2011, 6, 2216-2230. [CrossRef]

121. Abeeluck, D.; Benimadhu, S.P.; Rajkomar, B.; Ramnauth, R.K. Pesticide use in Mauritius. A report of a survey. Agric. Res. Ext. Unit Réduit Maurit. 1997, 22.

122. Sharma, H.C.; Saxena, K.B.; Bhagwat, V.R. The Legume Pod Borer, Maruca vitrata: Bionomics and Management. Bulletin 1999, 55, 42. Available online: http:/ / oar.icrisat.org/id/eprint/ 6608 (accessed on 5 August 2020).

123. Ekesi, S. Insecticide resistance in field populations of the legume pod-borer, Maruca vitrata Fabricius (Lepidoptera: Pyralidae), on cowpea, Vigna unguiculata (L.), Walp in Nigeria. Int. J. Pest. Manag. 1999, 45, 57-59. [CrossRef]

124. Mkindi, A.; Mpumi, N.; Tembo, Y.; Stevenson, P.C.; Ndakidemi, P.A.; Mtei, K.; Machunda, R.; Belmain, S.R. Invasive weeds with pesticidal properties as potential new crops. Ind. Crop. Prod. 2017, 110, 113-122. [CrossRef]

125. Tembo, Y.; Mkindi, A.G.; Mkenda, P.A.; Mpumi, N.; Mwanauta, R.; Stevenson, P.C.; Ndakidemi, P.A.; Belmain, S.R. Pesticidal plant extracts improve yield and reduce insect pests on legume crops without harming beneficial arthropods. Front. Plant Sci. 2018, 9, 1425. [CrossRef] [PubMed]

126. Araya, J.E.; Araya, M.; Guerrero, M.A. Effects of some insecticides applied in sublethal concentrations on the survival and longevity of Aphidius ervi (Haliday) (Hymenoptera: Aphidiidae) adults. Chil. J. Agric. Res. 2010, 70, 221-227. [CrossRef]

127. Liu, T.-X.; Chen, T.-Y. Effects of the insect growth regulator fenoxycarb on immature Chrysoperla rufilabris (Neuroptera: Chrysopidae). Fla. Entomol. 2001, 84, 628-633. [CrossRef]

128. Schneider, M.; Smagghe, G.; Pineda, S.; Vinuela, E. Action of insect growth regulator insecticides and spinosad on life-history parameters and absorption in third-instar larvae of the endoparasitoid Hyposoter didymator. Biol. Control 2004, 31, 189-198. [CrossRef]

129. Shoeb, M.A. Effect of some insecticides on the immature stages of the egg parasitoid Trichogramma evanescens. Egypt. Acad. J. Biol. Sci. 2010, 3, 31-38. [CrossRef]

130. Thomson, L.; Glenn, D.; Hoffmann, A. Effects of Sulfur on Trichogramma egg parasitoids in vineyards: Measuring toxic effects and establishing release windows. Anim. Prod. Sci. 2001, 40, 1165-1171. [CrossRef]

131. Munyuli MB, T.; Luther, G.C.; Kyamanywa, S. Effects of cowpea cropping systems and insecticides on arthropod predators in Uganda and the Democratic Republic of the Congo. Crop. Prot. 2007, 26, 114-126. [CrossRef]

132. Black, R. A Guide to the Development of Regulatory Frameworks for Microbial Biopesticides in Sub-Saharan Africa; African Agricultural Technology Foundation: Nairobi, Kenya, 2013; Available online: https:/ /bit.ly/2TGOwFA (accessed on 19 October 2020).

133. Macías, F.A.; Castellano, D.; Molinillo, J.M.G. Search for a standard phytotoxic bioassay for allelochemicals. Selection of standard target species. J. Agric. Food Chem. 2000, 48, 2512-2521. [CrossRef]

134. Isman, M.B. Botanical insecticides: For richer, for poorer. Pest. Manag. Sci. 2008, 64, 8-11. [CrossRef] [PubMed]

135. Moshi, A.P.; Matoju, I. The status of research on and application of biopesticides in Tanzania. Review. Crop. Prot. 2017, 92, 16-28. [CrossRef]

136. Leahy, J.; Mendelsohn, M.; Kough, J.; Jones, R.; Berckes, N. Biopesticide oversight and registration at the U.S. Environmental Protection Agency. ACS Symp. Ser. 2014, 1172, 3-18. [CrossRef]

137. Srinivasan, R. Integrating biopesticides in pest management strategies for tropical vegetable production. J. Biopestic. 2012, 5, 36-45.

138. Bravo, A.; Likitvivatanavong, S.; Gill, S.S.; Soberón, M. Bacillus thuringiensis: A story of a successful bioinsecticide. Insect Biochem. Mol. Biol. 2011, 41, 423-431. [CrossRef] 
139. Addae, P.C.; Ishiyaku, M.F.; Tignegre, J.B.; Ba, M.N.; Bationo, J.B.; Atokple, I.D.; Abudulai, M.; Dabiré-Binso, C.L.; Traore, F.; Saba, M.; et al. Efficacy of a cry1Ab Gene for control of Maruca vitrata (Lepidoptera: Crambidae) in Cowpea (Fabaceae). J. Econ. Entomol. 2020, 113, 974-979. [CrossRef]

140. Kumar, P.; Huang, L.Z.; Srinivasan, R. Effect of three commercial biopesticides of neem (Azadirachta indica) and Bacillus thuringiensis on legume pod borer (Maruca vitrata) (Lepidoptera: Crambidae) in Thailand. Int. J. Trop. Insect Sci. 2014, 34, 80-87. [CrossRef]

141. Srinivasan, R.; Yule, S.; Lin, M.Y.; Khumsuwan, C. Recent developments in the biological control of legume pod borer (Maruca vitrata) on the yard-long bean. Acta Hortic. 2015, 1102, 143-150. [CrossRef]

142. Traoré, F. Effects of Maruca vitrata multi-nucleopolyhedrovirus and neem oil, Azadirachta indica Juss on the eggs of the cowpea pod borer, Maruca vitrata Fabricius (Lepidoptera: Crambidae). Int. J. Trop. Insect Sci. 2019, 39, 333-339. [CrossRef]

143. Mehinto, J.T.; Loko, Y.L.E.; Kpindou, O.K.D.; Dannon, E.A.; Zanzana, K.; Kassa, P.; Adandonon, A.; Tamò, M. Management of the legume pod borer Maruca vitrata Fabricius (Lepidoptera: Crambidae) with field applications of the entomopathogenic fungus, Beauveria bassiana and a mixed formulation of the baculovirus MaviMNPV with emulsifiable neem oil. Afr. J. Agric. Res. 2020, 15, 113-121. [CrossRef]

144. Sokame, B.M.; Tounou, A.K.; Datinon, B.; Dannon, E.A.; Agboton, C.; Srinivasan, R.; Pittendrigh, B.R.; Tamo, M. Combined activity of Maruca vitrata multi-nucleopolyhedrovirus, MaviMNPV and oil from neem, Azadirachta indica Juss and Jatropha curcas L., for the control of cowpea pests. Crop. Prot. 2015, 72, 150-157. [CrossRef]

145. Srinivasan, R.; Tamo, M.; Lee, S.T.; Lin, M.Y.; Huang, C.C.; Hsu, Y.C. Towards developing a biological control program for legume pod borer (Maruca vitrata). In International Conference on Grain Legumes: Quality Improvement, Value Addition and Trade (No. RESEARCH); Indian Institute of Pulses Research: Kanpur, India, 2009; pp. 183-196.

146. Srinivasan, R.; Sevgan, S.; Tamò, M. Biopesticide-based sustainable pest management for safer production of vegetable legumes and brassicas in Asia and Africa. Pest. Manag. Sci. 2019, 75, 2446-2454. [CrossRef] [PubMed]

147. Akmal, M.; Freed, S.; Malik, M.N.; Gul, H.T. Efficacy of Beauveria bassiana (deuteromycotina: Hyphomycetes) against different aphid species under laboratory conditions. Pak. J. Zool. 2013, 45, 71-78.

148. Sayed, S.; Elarrnaouty, S.A.; Alotaibi, S.; Salah, M. Pathogenicity and side effect of indigenous Beauveria bassiana on Coccinella undecimpunctata and Hippodamia variegata (Coleoptera: Coccinellidae). Insects 2021, 12, 42. [CrossRef] [PubMed]

149. Mohammed, A.A. Lecanicillium muscarium and Adalia bipunctata combination for the control of black bean aphid, Aphis fabae. Biol. Control 2018, 63, 277-287. [CrossRef]

150. Fernández-Grandon, G.M.; Harte, S.J.; Ewany, J.; Bray, D.; Stevenson, P.C. Additive effect of botanical insecticide and entomopathogenic fungi on pest mortality and the behavioral response of its natural enemy. Plants 2020, 9, 173. [CrossRef] [PubMed]

151. Tumuhaise, V.; Ekesi, S.; Mohamed, S.A.; Ndegwa, P.N.; Irungu, L.W.; Srinivasan, R.; Maniania, N.K. Pathogenicity and performance of two candidate isolates of Metarhizium anisopliae and Beauveria bassiana (Hypocreales: Clavicipitaceae) in four liquid culture media for the management of the legume pod borer Maruca vitrata (Lepidoptera: Crambidae). Int. J. Trop. Insect Sci. 2015, 35, 34-47. [CrossRef]

152. Ekesi, S.; Maniania, N.K.; Lux, S.A. Mortality in three African tephritid fruit fly puparia and adults caused by the entomopathogenic fungi, Metarhizium anisopliae and Beauveria bassiana. Biocontrol Sci. Technol. 2002, 12, 7-17. [CrossRef]

153. Saruhan, I. Efficacy of some entomopathogenic fungi against Aphis fabae Scopoli (Hemiptera: Aphididae). Egypt. J. Biol. Pest. Control 2018, 28, 4-9. [CrossRef]

154. Saruhan, I.; Erper, I.; Tuncer, C.; Akca, I. Efficiency of some entomopathogenic fungi as biocontrol agents against Aphis fabae scopoli (Hemiptera: Aphididae). Pak. J. Agric. Sci. 2015, 52, 273-278.

155. Boni, S.B.; Mwashimaha, R.A.; Mlowe, N.; Sotelo-Cardona, P.; Nordey, T. Efficacy of indigenous entomopathogenic fungi against the black aphid, Aphis fabae Scopoli under controlled conditions in Tanzania. Int. J. Trop. Insect Sci. 2020, 2009, 1-9. [CrossRef]

156. Pervez, R.; Rao, U. Infectivity of entomopathogenic nematodes against the legume pod-borer, Maruca vitrata Fabricius, infesting pigeon pea. J. Helminthol. 2021, 95, e15. [CrossRef]

157. Darbro, J.M.; Thomas, M.B. Spore persistence and likelihood of aeroallergenicity of entomopathogenic fungi used for mosquito control. Am. J. Trop. Med. Hyg. 2009, 80, 992-997. [CrossRef]

158. Jaronski, S.T. Ecological factors in the inundative use of fungal entomopathogens. BioControl 2010, 55, 159-185. [CrossRef]

159. Lacey, L.A.; Mesquita, A.L.; Mercadier, G.; Debire, R.; Kazmer, D.J.; Leclant, F. Acute and sublethal activity of the entomopathogenic fungus Paecilomyces fumosoroseus (Deuteromycotina: Hyphomycetes) on adult Aphelinus asychis (Hymenoptera: Aphelinidae). Environ. Entomol. 1997, 26, 1452-1460. [CrossRef]

160. Roy, H.E.; Pell, J.K. Interactions between entomopathogenic fungi and other natural enemies: Implications for biological control. Biocontrol Sci. Technol. 2000, 10, 737-752. [CrossRef]

161. Shipp, J.L.; Zhang, Y.; Hunt, D.W.A.; Ferguson, G. Influence of humidity and greenhouse microclimate on the efficacy of Beauveria bassiana (Balsamo) for control of greenhouse arthropod pests. Environ. Entomol. 2003, 32, 1154-1163. [CrossRef]

162. Rattan, R.S. Mechanism of action of insecticidal secondary metabolites of plant origin. Crop. Prot. 2010, 29, 913-920. [CrossRef]

163. Grzywacz, D.; Stevenson, P.C.; Mushobozi, W.L.; Belmain, S.; Wilson, K. The use of indigenous ecological resources for pest control in Africa. Food Secur. 2014, 6, 71-86. [CrossRef] 
164. Bonsignore, C.; Vacante, V. Influences of botanical pesticides and biological agents on Orius laevigatus- Frankliniella occidentalis dynamics under greenhouse conditions. J. Plant Prot. Res. 2012, 52, 15-23. [CrossRef]

165. Tunca, H.; Kilinçer, N.; Özkan, C. Side-effects of some botanical insecticides and extracts on the parasitoid, Venturia canescens (Grav.) (Hymenoptera: Ichneumonidae). Turk. J. Entomol. 2012, 36, 205-214. [CrossRef]

166. Simmonds, M.; Manlove, J.; Blaney, W.; Khambay, B. Effects of selected botanical insecticides on the behaviour and mortality of the glasshouse whitefly Trialeurodes vaporariorum and the parasitoid Encarsia formosa. Entomol. Exp. Appl. 2002, 102, 39-47. [CrossRef]

167. Swaminathan, R.; Jat, H.; Hussain, T. Side effects of a few botanicals on the aphidophagous Coccinellids. J. Biopestic. 2010, 3 , 81-84.

168. Belmain, S.; Stevenson, P. Ethnobotanicals in Ghana: Reviving and modernizing age-old farmer practice. Pestic. Outlook 2001, 12, 233-238. [CrossRef]

169. Bahar, H.; Islam, A.; Mannan, A.; Uddin, J. Effectiveness of some botanical extracts on bean aphids attacking yard-long beans. J. Entomol. 2007, 4, 136-142. [CrossRef]

170. Kayange, C.D.M.; Njera, D.; Nyirenda, S.P.; Mwamlima, L. Effectiveness of Tephrosia vogelii and Tephrosia candida extracts against common bean aphid (Aphis fabae) in Malawi. Adv. Agric. 2019, 2019, 1-6. [CrossRef]

171. Biniaś, B.; Gospodarek, J. Effect of water extract from Chamomile on black bean aphid and Colorado potato beetle. J. Ecol. Eng. 2017, 18, 118-124. [CrossRef]

172. Ugwu, J.A. Insecticidal activity of some botanical extracts against legume flower thrips and legume pod borer on cowpea Vigna unguiculata L. Walp. J. Basic Appl. Zool. 2020, 81. [CrossRef]

173. Singh, P.; Prakash, B.; Dubey, N.K. Insecticidal activity of Ageratum conyzoides L., Coleus aromaticus Benth. and Hyptis suaveolens (L.) Poit essential oils as fumigant against storage grain insect Tribolium castaneum Herbst. J. Food Sci. Technol. 2014, 51, 2210-2215. [CrossRef]

174. Diniz, J.F.S.; da Silva, P.R.; dos Reis, M.R.; Endo, R.T.; Ramos, R.S.; Fernandes, F.L.; da Silva, Í.W. Insecticide activity of weeds to pests of stored products and crops. J. Agric. Sci. 2014, 6, 194-199. [CrossRef]

175. Souza, I.L.; Tomazella, V.B.; Santos, A.J.N.; Moraes, T.; Silveira, L.C.P. Parasitoids diversity in organic Sweet pepper (Capsicum annuum) associated with Basil (Ocimum basilicum) and Marigold (Tagetes erecta). Braz. J. Biol. 2019, 79, 603-611. [CrossRef] [PubMed]

176. Reddy, S.E.; Dolma, S.K.; Verma, P.K.; Singh, B. Insecticidal activities of Parthenium hysterophorus L. extract and parthenin against diamondback moth, Plutella xylostella (L.) and aphid, Aphis craccivora Koch. Toxin Rev. 2018, 37, 161-165. [CrossRef]

177. Sahayaraj, K.; Kombiah, P.; Dikshit, A.K. Chemical constituents of the essential oils of Tephrosia purpurea and Ipomoea carnea and their repellent activity against Odoiporus longicollis. J. Serb. Chem. Soc. 2015, 80, 465-473. [CrossRef]

178. Koch, M.S.; Ward, J.M.; Levine, S.L.; Baum, J.A.; Vicini, J.L.; Hammond, B.G. The food and environmental safety of Bt crops. Front. Plant Sci. 2015, 6, 283. [CrossRef] [PubMed]

179. Ba, M.N.; Huesing, J.E.; Tamò, M.; Higgins, T.J.V.; Pittendrigh, B.R.; Murdock, L.L. An assessment of the risk of Bt-cowpea to non-target organisms in West Africa. J. Pest. Sci. 2018, 91, 1165-1179. [CrossRef]

180. Nyangau, P.; Muriithi, B.; Diiro, G.; Akutse, K.S.; Subramanian, S. Farmers' knowledge and management practices of cereal, legume and vegetable insect pests, and willingness to pay for biopesticides. Int. J. Pest. Manag. 2020, 1-13. [CrossRef]

181. Constantine, K.L.; Kansiime, M.K.; Mugambi, I.; Nunda, W.; Chacha, D.; Rware, H.; Makale, F.; Mulema, J.; Lamontagne-Godwin, J.; Williams, F.; et al. Why don't smallholder farmers in Kenya use more biopesticides? Pest. Manag. Sci. 2020, 76, 3615-3625. [CrossRef]

182. Rubiales, D.; Fondevilla, S.; Chen, W.; Gentzbittel, L.; Thomas, J.V. Achievements and challenges in legume breeding for pest and disease resistance. Crit. Rev. Plant Sci. 2015, 34, 195-236. [CrossRef]

183. Adati, T.; Tamò, M.; Yusuf, S.R.; Downham, M.C.A.; Singh, B.B.; Hammond, W. Integrated pest management for cowpea-cereal cropping systems in the West African savannah. Int. J. Trop. Insect Sci. 2007, 27, 123-137. [CrossRef]

184. Halder, J.; Srinivasan, S. Varietal screening and role of morphological factors on distribution and abundance of spotted pod borer, Maruca vitrata (Geyer) on cowpea. Ann. Plant Prot. Sci. 2011, 19, 71-74.

185. Yusuf, S.R. Infestation and Damage by Maruca vitrata Fabricius (Lepidoptera: Pyralidae) on Some Cowpea Lines under Different Cropping Systems in Kano, Nigeria. Ph.D. Thesis, Abubakar Tafawa Balewa University, Bauchi, Nigeria, 2007; 155p.

186. Huesing, J.; Romeis, J.; Ellstrand, N.; Raybould, A.; Hellmich, R.; Wolt, J.; Ehlers, J.; Dabiré, C.; Fatokun, C.; Hokanson, K.; et al Regulatory considerations surrounding the deployment of Bt-expressing cowpea in Africa: Report of the deliberations of an expert panel. GM Crop. 2011, 2, 211-224. [CrossRef] [PubMed]

187. Mwangi, S.N.; Deng, A.L.; Kamau, A.W. Response of Kenyan varieties of common bean, Phaseolus vulgaris L., to infestation by Aphis fabae Scopoli. Afr. Entomol. 2008, 16, 196-202. [CrossRef]

188. Esmaeili-Vardanjani, M.; Askarianzadeh, A.; Saeidi, Z.; Hasanshahi, G.H.; Karimi, J.; Nourbakhsh, S.H. A study on common bean cultivars to identify sources of resistance against the black bean aphid, Aphis fabae Scopoli (Hemiptera: Aphididae). Arch. Phytopathol. Plant Prot. 2013, 46, 1598-1608. [CrossRef]

189. Shannag, H.K.; Obeidat, W.M. Interaction between plant resistance and predation of Aphis fabae (Homoptera: Aphididae) by Coccinella septempunctata (Coleoptera: Coccinellidae). Ann. Appl. Biol. 2008, 152, 331-337. [CrossRef] 
190. Razmjou, J.; Fallahi, A. Effects of sugar beet cultivar on development and reproductive capacity of Aphis fabae. Bull. Insectology 2009, 62, 197-201.

191. Adipala, E.; Nampala, P.; Karungi, J.; Isubikalu, P. A review on options for management of cowpea pests: Experiences from Uganda. Integr. Pest. Manag. Rev. 2000, 5, 185-196. [CrossRef]

192. Nampala, P.; Kyamanywa, S.; Ogenga-Latigo, M.W.; Adipala, E.; Karungi, J.; Oyobo, N.; Jackai, L.E.N. Integrated management of major field pests of cowpea in eastern Uganda. Afr. Crop. Sci. J. 1999, 7, 479-486. [CrossRef]

193. Karel, A.K. Effects of intercropping with maize on the incidence and damage caused by pod borers of common beans. Environ. Entomol. 1993, 22, 1076-1083. [CrossRef]

194. Omolo, E.O.; Nyambo, B.; Simbi CO, J.; Ollimo, P. The role of host plant resistance and intercropping in integrated pest management (IPM) with specific reference to the Oyugis project. Int. J. Pest. Manag. 1993, 39, 265-272. [CrossRef]

195. Bottenberg, H.; Tamo, M.; Singh, B.B. Occurrence of phytophagous insects on wild Vigna sp. and cultivated cowpea: Comparing the relative importance of host-plant resistance and millet intercropping. Agric. Ecosyst. Environ. 1998, 70, 217-229. [CrossRef]

196. Emeasor, K.C.; Ezueh, M.I. The influence of companion crops in the control of insect pests of cowpea in intercropping systems. Trop. Agric. 1997, 74, 285-289.

197. Asiwe, J.A.N.; Nokoe, S.; Jackai, L.E.N.; Ewete, F.K. Does varying cowpea spacing provide better protection against cowpea pests? Crop. Prot. 2005, 24, 465-471. [CrossRef]

198. Ekesi, S.; Dike, M.C.; Ogunlana, M.O. Relationship between planting dates and damage by the legume pod-borer, Maruca testulalis (Geyer) (Lepidoptera: Pyralidae) on cowpea, Vigna unguiculata (L) Walp in Nigeria. Int. J. Pest. Manag. 1996, 42, 315-316. [CrossRef]

199. Latigo-Ogenga, M.W.; Baliddawa, C.W.; Ampofo, J.K.O. Factors influencing the incidence of the black bean aphid, Aphis fabae Scop., on common beans intercropped with maize. Afr. Crop. Sci. J. 1993, 1, 49-58.

200. Azimi, S.; Amini, R. Population density of Aphis fabae Scopoli (Hemiptera, Aphididae) and its natural enemies in intercropping of faba bean (Vicia faba L.) and dragonhead (Dracocephalum moldavica L.). J. Biodivers. Environ. Sci. 2015, 6, 380-388.

201. Agunbiade, T.A.; Sun, W.; Coates, B.S.; Traore, F.; Ojo, J.A.; Lutomia, A.N.; Bello-Bravo, J.; Miresmailli, S.; Huesing, J.E.; Agyekum, M.; et al. Insect pests and integrated pest management techniques in grain legume cultivation. In Achieving Ustainable Cultivation of Grain Legumes, Vol. 1: Advances in Breeding and Cultivation Techniques; Sivasankar, S., Bergvinson, D., Gaur, P., Agrawal, S., Beebe, S., Tamò, M., Eds.; Burleigh Dodds: Cambridge, UK, 2018; pp. 297-320.

202. Singh, S.R.; Jackai, L.E.N.; Dos Santos, J.H.R.; Adalla, C.B. Insect pests of Cowpea. In Insect Pests of Tropical Food Legumes; Singh, S.R., Ed.; Wiley: Chichester, UK, 1990; pp. 43-89.

203. Ajeigbe, H.A.; Singh, B.B. Integrated pest management in cowpea: Effect of time and frequency of insecticide application on productivity. Crop. Prot. 2006, 25, 920-925. [CrossRef]

204. Nabirye, J.; Nampala, P.; Ogenga-Latigo, M.W.; Kyamanywa, S.; Wilson, H.; Odeke, V.; Iceduna, C.; Adipala, E. Farmerparticipatory evaluation of cowpea integrated pest management (IPM) technologies in Eastern Uganda. Crop. Prot. 2003, 22, 31-38. [CrossRef]

205. Elisante, F.; Ndakidemi, P.A.; Arnold, S.E.J.; Belmain, S.R.; Gurr, G.M.; Darbyshire, I.; Xie, G.; Tumbo, J.; Stevenson, P.C. Enhancing knowledge among smallholders on pollinators and supporting field margins for sustainable food security. J. Rural. Stud. 2019, 70, 75-86. [CrossRef] 